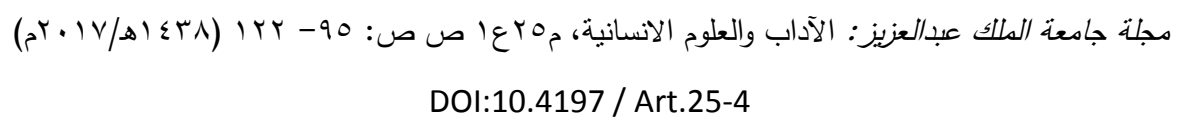

DOI:10.4197 / Art.25-4

السلك " نظم نثر تصريف ابن عصفور" والتعليق عليه لأحد علماء النحو

في القرن الثامن الهجري دراسة وتحقيق " مواضع الزيادة "

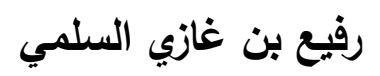

جامعة الملك عبدالعزيز

مستخطص هذا البحث بستهف دراسة كتاب تصريفي من تراث أمتنا المخطوط، عبارة عن نظٍِ

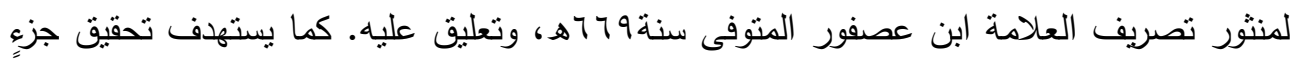

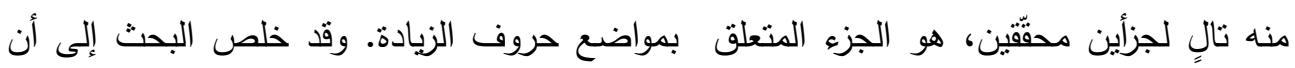

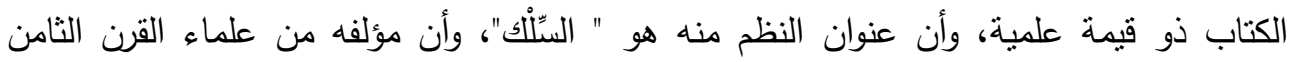
الهجري، وأن له رأيا في بعض المسائل التصريفية، وأنه على علم مثين بعلوم اللغة المختلفة، وأنه

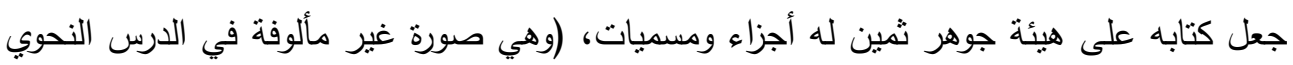
عموما والتصريفي خصوصا ). الكلمات المفتاهية: ابن عصفور - النحو والصرف - النظطوطات العربية دراسة الكتاب (محتواه)

والمؤلف فعل العكس ، قدّم بابي " أبنية الأسماء

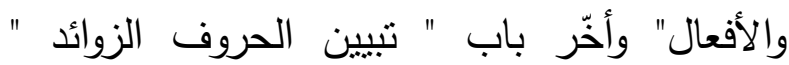
لتكون قبل باب " حروف الزيادة ، وذكر الأماكن

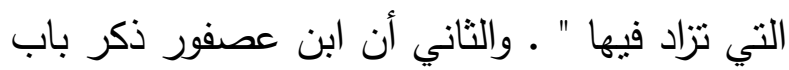

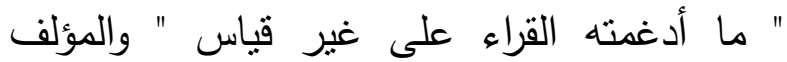

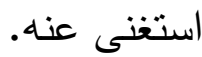

هذا الكتاب مشتمل على نظم وتعليق عليه .

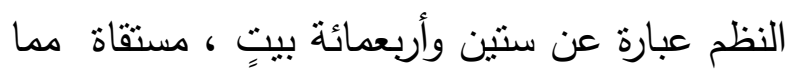

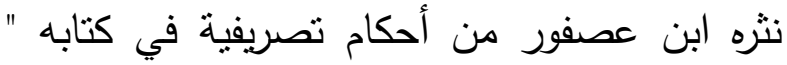

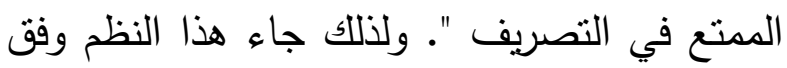

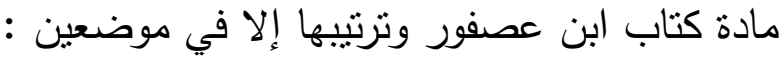

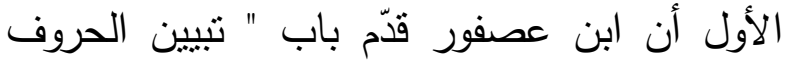
الزوائد" على بابي " أبنية الأسماء والأفعال "، التروف 
وطريقته في التعليق أنه يورد مايقتيه الحكم

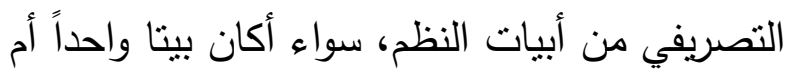
اثثين أم أكثر من ذلك، ثم يُعلّق عليها.

\section{عنــوانه}

اطلع بروكلمان على إحدى نسختي الكتاب

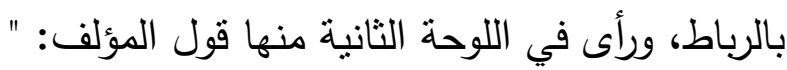
هذا هو الطرف الأول من السلك والعنوان فالكئ ومقام اللؤلؤ منه والعقيان " فاعتقد أنه عنوان الكتاب، فقال

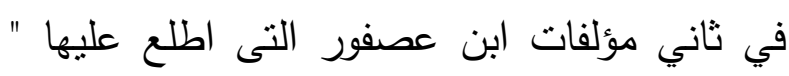

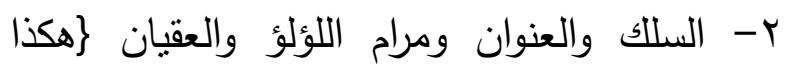

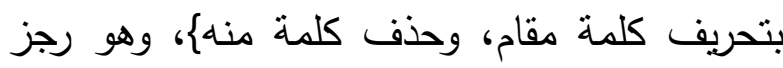

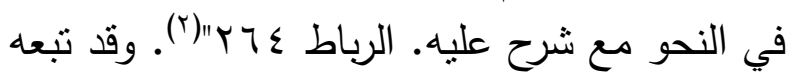
في هذا بعض محققي كتب ابن عصفور (r). وهو وهم وقع فيه بسبب التعجل، وعدم القراءة الفاحصة للكتاب، إذ المؤلف صرح فيه أكثر من مرّة

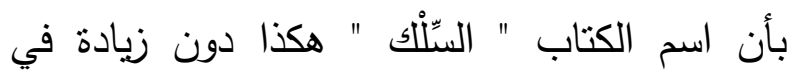
المسمى، وهو نظمّ لنثر تصريف ابن عصفور ، فقال في أول النظم عقب حديثه عن تصريف ابن

عصفور (๕):

نظمتُ نثرَ دُرِّه في سللكِ سهلٍ مهذِبٍ قريبِ السلكِ

$$
\text { وقال في آخره(0) : }
$$

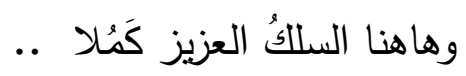

وقال في أول التعليق:" فالقصد بهذا التعليق تصوير ما تضمنه السلك الذي نظمنا فرائده..."

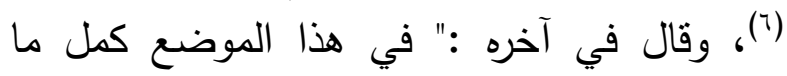

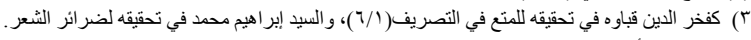

وقد بدأ بعد الحمد والصلاة على النبي

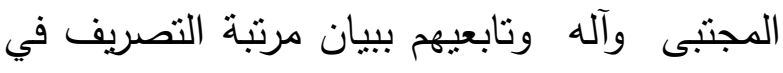
علم العربية، وسبب نظمه نثر تصريف ابن عصفور

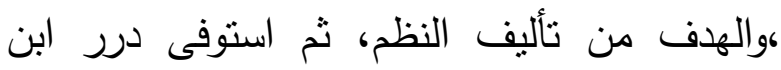

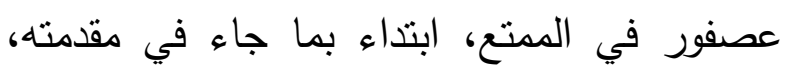

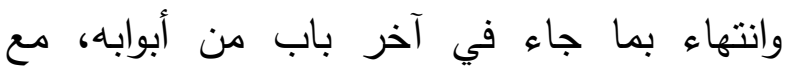

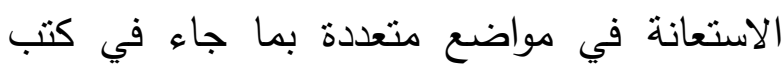

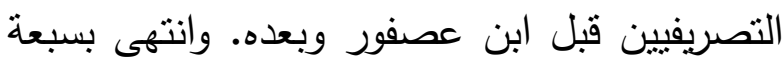

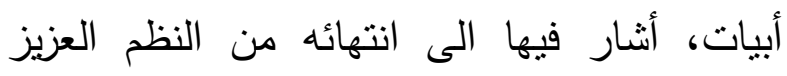

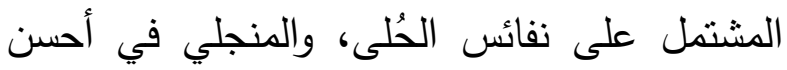

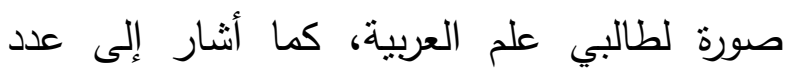
أبيات النظم على النحو الذي ذكرنا، وختم بما بدأ من الحمد والصلاة والسلام على الرسول، وآله والتابعين وتابعيهم.

أمّا التعليق فقد أبان عنه المؤلف بقوله:" فالقصد بهذا التعليق تصوير ما تضمنه السلك الذي فئن نظمنا فرائده ضابطا في التصريف، وجعلنا فئا نفائسه

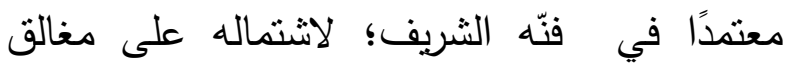

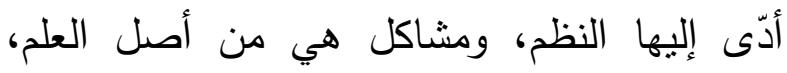

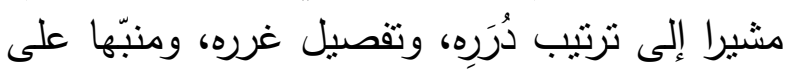

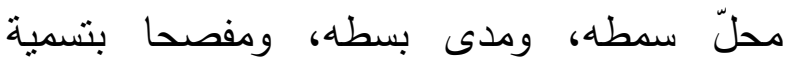
الطرفين منه والواسطة وما بينهما من عقدٍ ورابطةٍة وفيطة

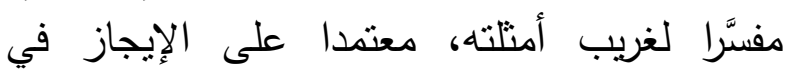

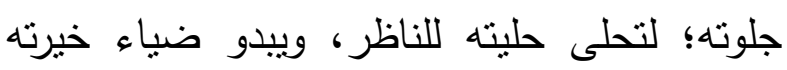

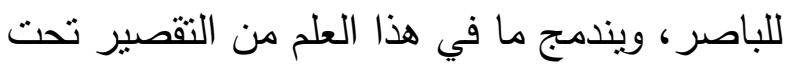

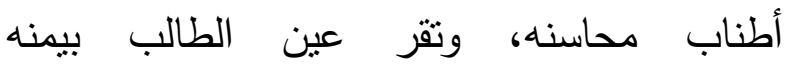
وتيامنه..."("). وقد يضيف لهذا الذي ذانئ ذكره مالم يسعه

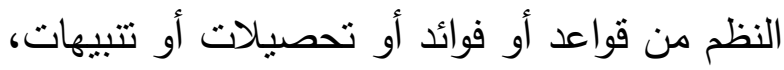
وقد يُعرب أحيانا بعض ألفاظ الأبيات، ويذكر مافيها من محسنات بديعية. 
السمط الآخر:" هذا سمط اجتمعت فيه نفائس

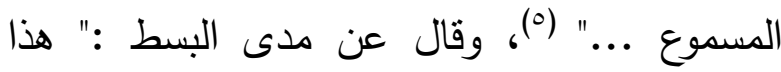

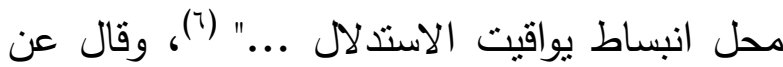
مسمى الطرف الأول :" هذا هو الطرف الأول من

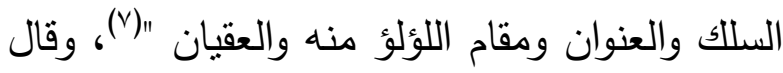

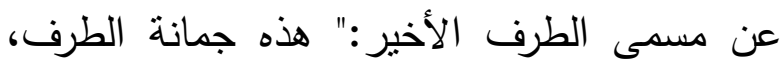
فيه من المباني والطرف ما يحوز به المتحلي قصب السبق "(^).وقال عن مسمى الواسطة:" هذا القول واسطة السلك، وصفوة خلاص السبك"(9).

ومن هنا، وتحديدا من تسمية المؤلف للطرف

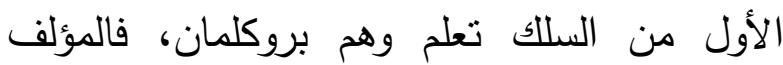

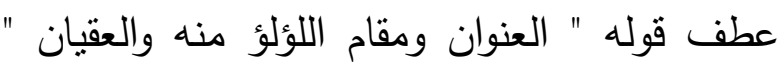
على قوله " الطرف الأول" ، ولم يعطفه على لفظ ولى "السلك"، بدليل ما جاء في المسميات الأخرى، و وله كأنه قال: "هذا هو الطرف الأول، والعنوان ومقام اللؤلؤ والعقيان من السللك"، وبروكلمان فعل خلافه . ولو أخذنا بفعل بروكلمان لبقي الطرف الأول من من

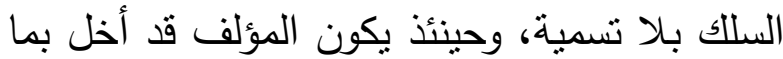

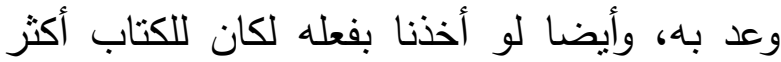

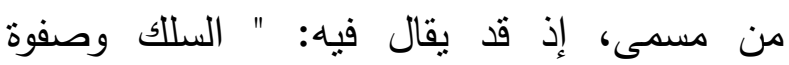
خلاصة السبك " أخذا من قول المؤلف في تسمية الواسطة :" هذا القول واسطة السلك ، وصفوة

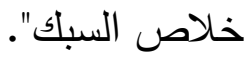

وعلى هذا الذي تقرر يكون مسمى الكتاب

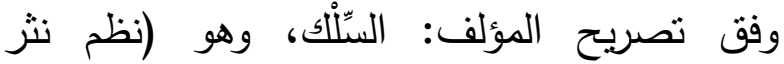
تصريف ابن عصفور) ـ أما ما جاء عليه للمؤلف
وعدنا به من نظم نثز تصريف ابن عصفور في سلك سهل مهذب قريب السلك"(1). ومراده بالسلك الخيط، كأنه نظم نثز تصريف ابن عصفور في خيط سهل مهذب قريب الحفظ، يقول في شرحه لبيت النظم : نظمتُ نثرَ دُرِّه في سلكِ سهلٍ مهذِب قريبِ السلكِ:" والسلك بالكسر لغة هو الخيط، وبالفتح مصدر من سلك، ومعناه إما نفس النظم، أي قربب النظم ، وإما نفس السلوك، من قولهم: سلك الرجل الطريق، أي قطعه بالمشي، والمراد بالأول الخيط، وبالثناني الحفظ، إذ ما قرب للسلك أو السلوك فهو قريب

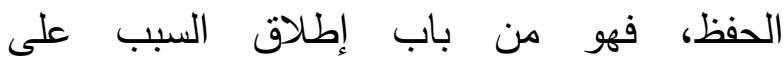

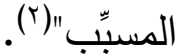
وقد جعل المؤلف هذا السلك على هيئة جوهر ثمين، له طرفان وواسطة وسمطان، وبين الطرفين

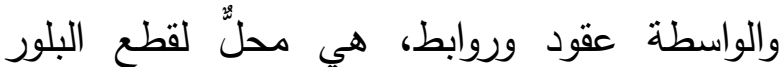
ومقام اللؤلؤ والعقيان، وكل ما يزين الجوهر ويوشِيّه. ووعد في مقدمـة التعليـق بالتتبيـه على محل

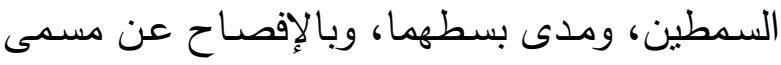
الطـرفين والواسـطة ومـا بينهمـا، فقـال:" ... ومنبهـا على محل سمطه ، ومدى بسطه ، ومفصحا بتسمية ولهية

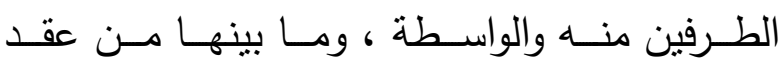
ورابطة "(r).

ووفى بما وعد، فقال عن محل السمط الأول:"

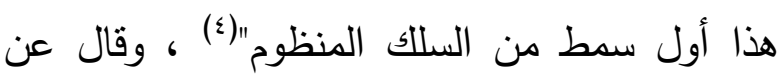


V V Vه، وابن هثام الأنصاري المتوفى سنة ( ( ) "

وهذه النسبة هي الصحيحة؛ لما ذكرته الدكتورة

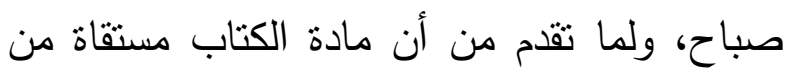

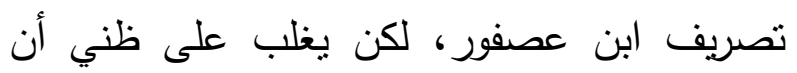

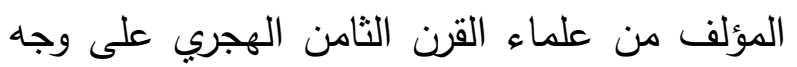

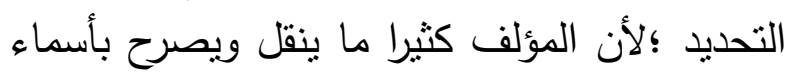

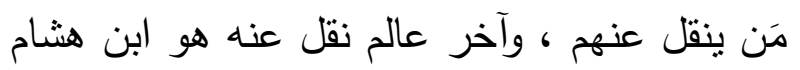

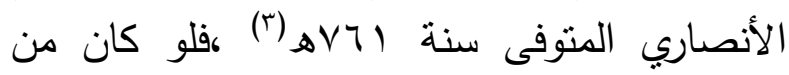
علماء ما بعد القرن الثامن لوجدنا نقلا له عن عله علهاء الهاء

$$
\text { متأخرين عن هذا القرن. }
$$

\section{قيمته (4) - (4) - (4)}

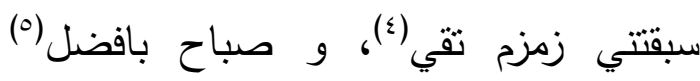

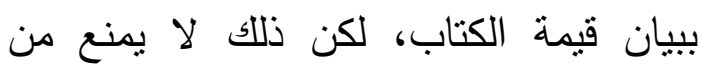

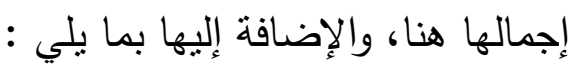

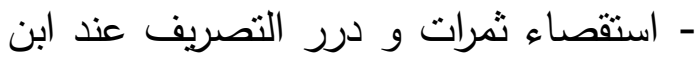
عصفور في كتابه " الممتع في التصريف" والزيادة عليها من كتب الفارسي، وابن جني، وابن ماللك،

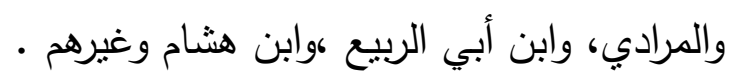

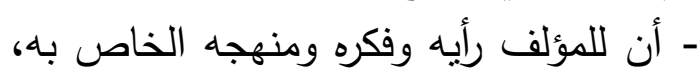
فقد أبدع في نظم علم التصريف، وجعل أجزاء

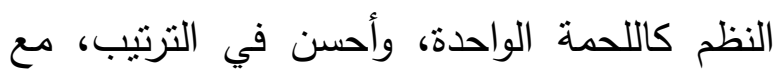

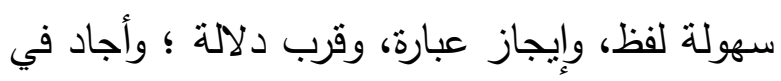

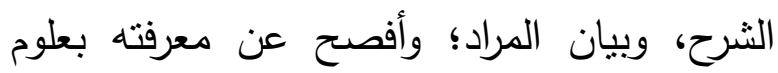
مختلفة، نحوا بإعراب بعض ألفاظ الأبيات، وبلاغة معنة

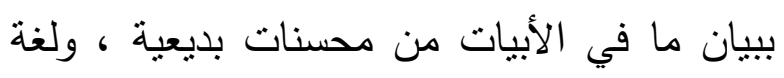

(r) الدرس الصرفي في شرح السلك و العوان ( ج).

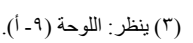

نفسه من بيان وإيضاح فإنما هو تعليقٌ بنص

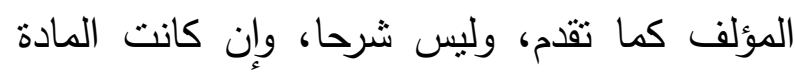
التي وردت به بصدق عليها مسمى الثرح • فردان

\section{مؤلفـــهـ}

جاءت النسختان الخطيتان اللتان و وققت عليهما لهذا الكتاب من غير ذكر لاسم المؤلف، ولم الفي يترك المؤلف في الكتاب ما يدلّ عليه أو يشير إليه لإنيه

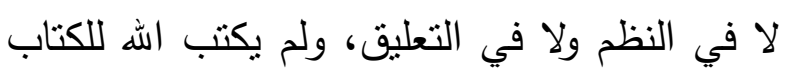

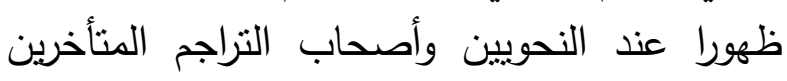

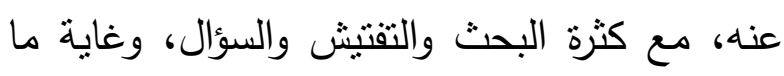
وقفت عليه في هذا ثلاث نِسَبِ:

أولها : أن بروكلمان اطلع على إحدى نسختي

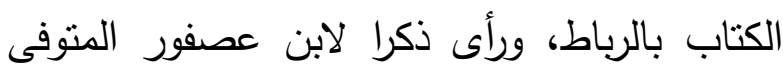

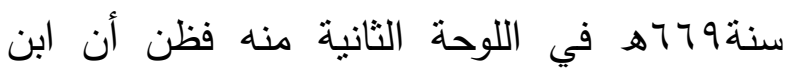
عصفور مؤلفه، وقد تقدم كلامه .

ثانيها: أن أحد القائمين على المكتبة العامة

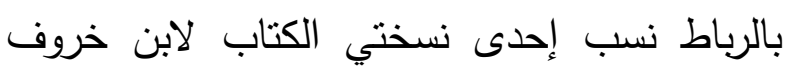

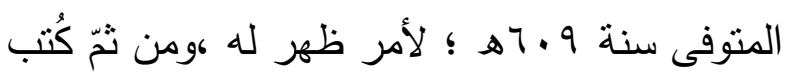
ذلك في بيانات هذه النسخة .

ثالثها: أن زمزم تقي، و صباح بافضل رجّحتا

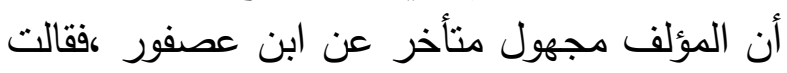

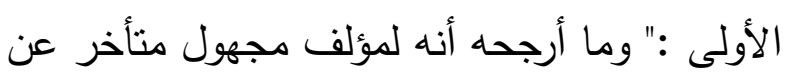

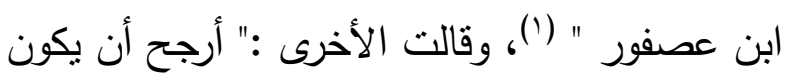

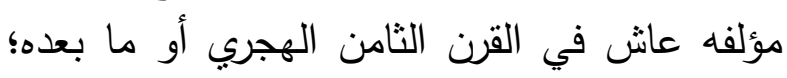

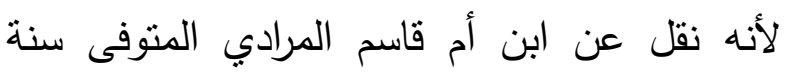


النظير" في دليل "الخروج عن النظير ": "وما قال عندي ضعيف" (0)

ولعل من صور اجتهاده - أيضا- أنه لم يكتف بعبارات التصريفين المتعددة في جمع حروف وهن الزيادة، فقال:" وقد جمعناها في قولنا : أنستها ليومِ،

$$
\text { وهو حسن" (־). }
$$

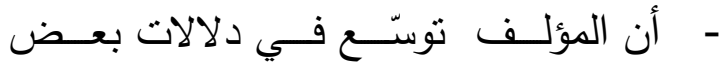

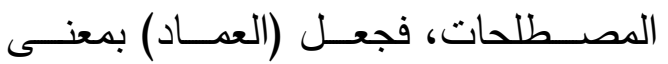

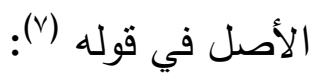

وغَيْرُ ما سِوَى المُضناعَفِ عِمَاذ

ونون الوقاية بمعنى نون الاحتماء في قوله (^):

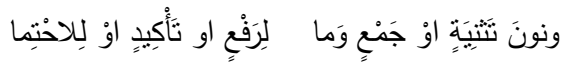

$$
\text { و( النقل) بمعن الزيادة في قوله (9): }
$$

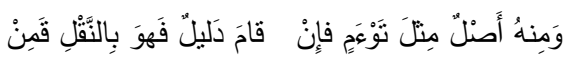

- أن المؤلف اخترع للكتاب صورة بهية غير مألوفة في الدرس النحوي، إذ جعله على هيئة جوهر ثمين على ما تقدم ذكره.

\section{نسخd}

اعتمدت في تحقيق هذا الجزء من هذا
بتفسير غريب الأمتلة التصريفية .كما اجتهد وأبدى وجهة نظره في مسائل مختلفة، وخالف ابن عصفور في أكثر من موضوع • فعلى سبيل المثال ما رآه ابن عصفور في "باب الزيادة" من فصل الميم عن الهزةة، والألف عن الواو والياء، وإفراد كل حرف من هذه الحروف بحكم مستقل رآه المؤلف العكس، فالميم تضم إلى الهمزة؛ لاتحادهما في الحكم أو تقاربهما، و الواو والياء تضمان إلى الألف كلاتحادهما كذلك في الحكم أو تقاربهما(').وما جعله ابن عصفور محتملا لأصالة اللام وزيادتها في: فيشلة وهيقل وطيسل جعله المؤلف قاطعا

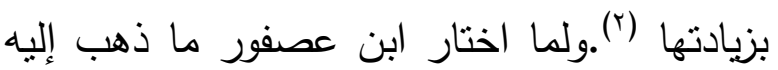
بعضهم من أن ألف (واو) منقلبة عن الواو كولم يختر ما ذهب إلبه آخرون من أن الألف منقلبة عن ياء - قال المؤلف بعد أن ذكر القولين:" وهو

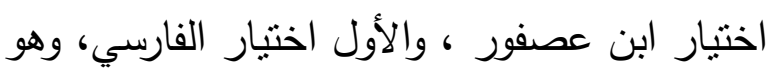

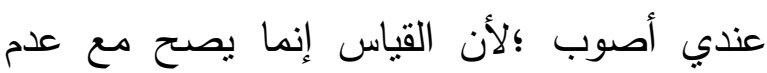
المعارض، وهو هنا قائم ..." (זّ). وأيضا قال معقبّا على حديث ابن عصفور عن القسم الذي يكون فيه الإبدال قليلا ، أو في لغة بعض العرب:" والحق أن الأليث به كتب اللغة، لا كتب التصريف كما ذكرنا "(๕). وما فعله المؤلف مع ابن عصفور فعله أيضا- مع غيره ، فقال في إدراج المرادي " دليل الدخول في أوسع البابين عند لزوم الخروج عن إن لن 
الرابعة : أن بهما التزاما بنظام التعقيبة ، " وهي الكلمة التي تكتب في أسفل الصفحة اليمنى لتنل التهل على بدء الصفحة التي تليها "(').

الخامسة : خلو هوامشهما من التعليقات إلا ما كتب

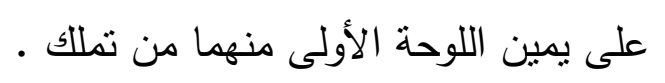

السادس : أن أبيات النظم فيهما قد ضبطت بالثكل

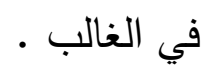

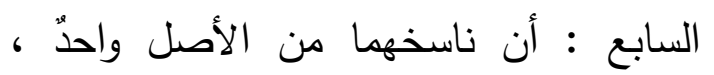

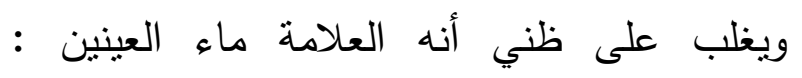

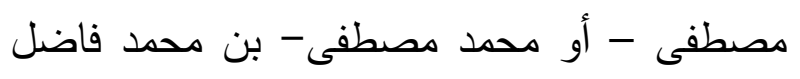

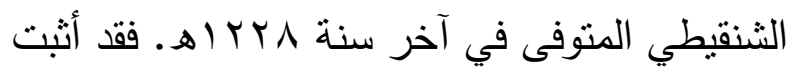
الزركلي (r) في أنثاء ترجمته له له صورةً مخطوطةٍ

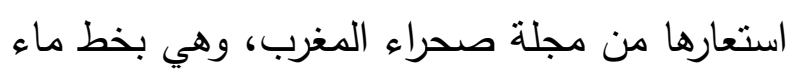

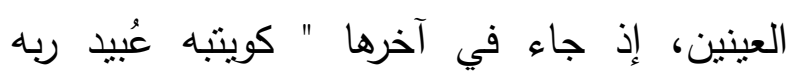
،وأسير ذنبه ماء العينين بن شيخه محمد فاضل فئل غفر الله لهم وللمسلمين ". وخط هذه المخطوطة هو لهاه خط نسختي هذا الكتاب نفسه.

وقد امنازت النسخة الأولى (أ) عن النسخة الأخرى (ب) بأمرين: الأول : أنها قد قوبلت الألت

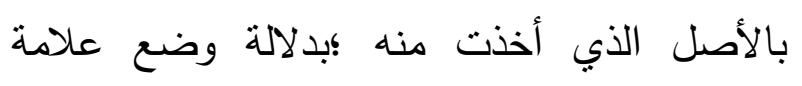
المقابلة والمراجعة (دائرة منقوط بداخلها) في نهاية لإنه شرح كل مجموعة مترابطة من أبيات النظم ـ الثاني

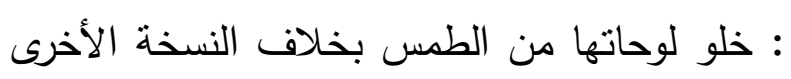

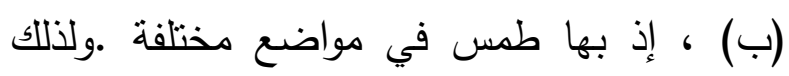

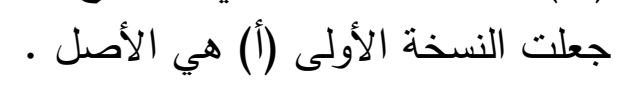

الكتاب على نسختين خطيتين كاملتين محفوظتين بالمكتبة العامة بالرباط، الأولى برقم

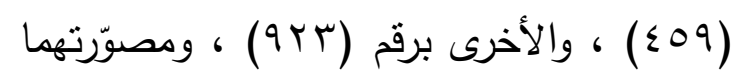

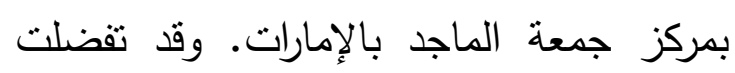

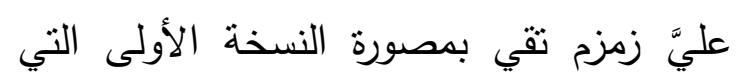

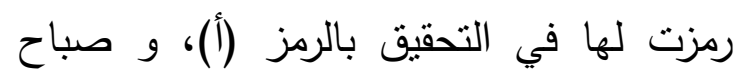

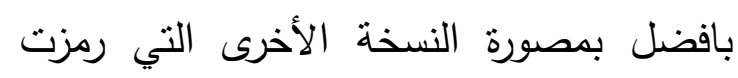

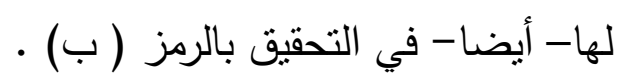

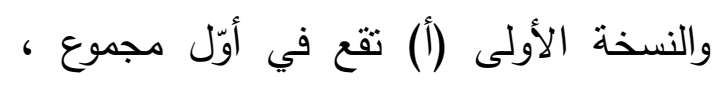

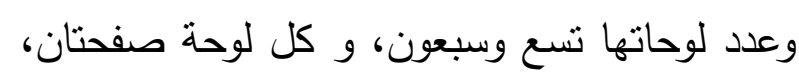

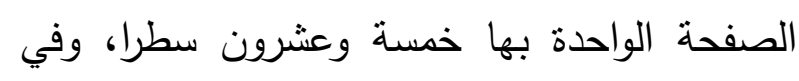
السطر الواحد ما بين ست عشرة إلى سبع عشرة كلمة. والنسخة الثانية (ب) في أوّل مجموع أيضا، و

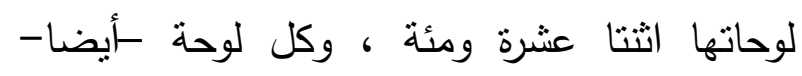

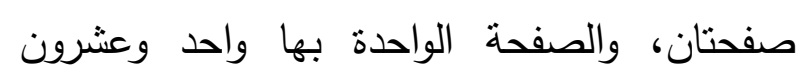

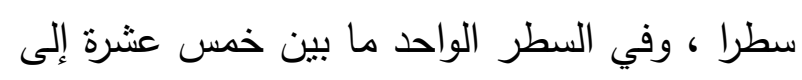

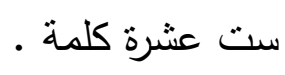
وبين النسختين توافق من ست جهات : الأولى: أنهما مكتوبتان بخط أندلسي مقروء • إلا في النادر الادل الن الثانية : أن بهما في مواضع قليلة سقطا، وتحريفات، وأخطاء نحوية وكتابية .

الثالثة : أنهما منسوختان من أصل واحد ، بدليل نطابق السقط والتحريف والخطأ النحوي والكتابي 
هذا محلُ انبساطِ أنوارِ يَوَاقيتِ الاستدلالِ،

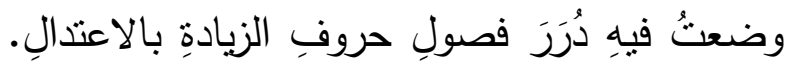

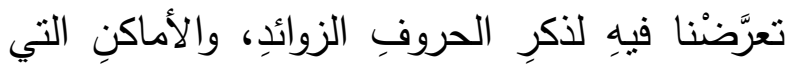

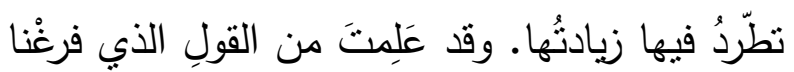

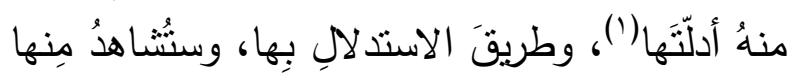

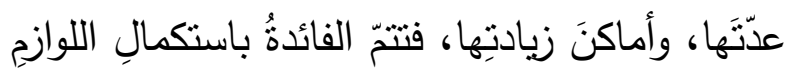
المُشارِ إليها في قولِنا (r) :

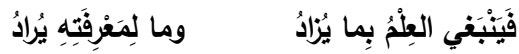

وبنّضحُ ما عسى أن يكونَ صعْبا عن الفكرِ

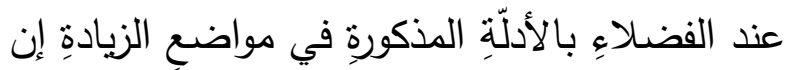

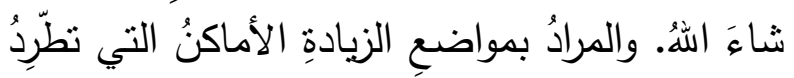

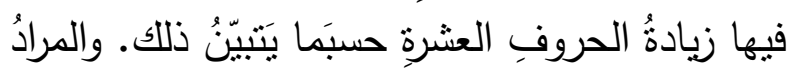

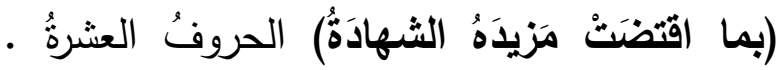

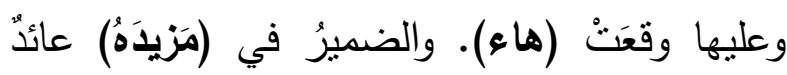

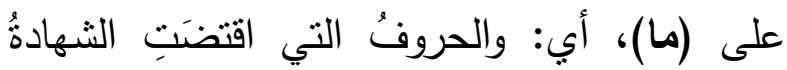
زيادتَها.

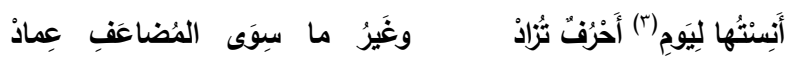
$[ب-10]$

بَدأُنا هُنا بما أخِّرْنا في الترجمةِ ردّا للعَجُزِ

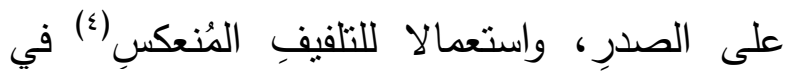

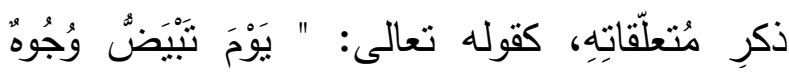

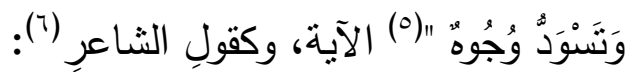

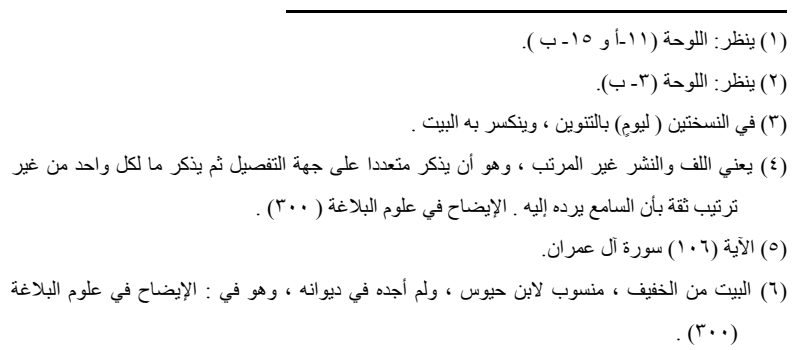

\section{منهج التحقيق}

بعد أن عرفتُ قيمة الكتاب السابق ذكرها، وبعد أن نأكدتُ من أنّ الكتاب كامل غير فير

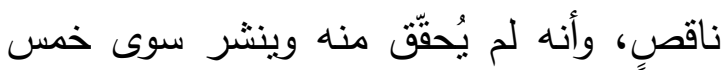

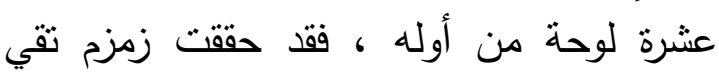

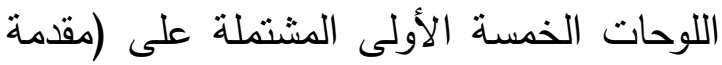
المؤلف وأهمية علم التصريف ومنزلته وتعريفه وتقسيمه، وما يدخله ومالا يدخله، وأبنية

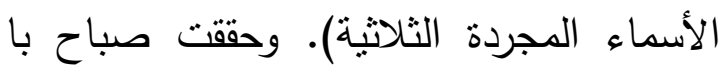
فضل تسع لوحات بعدها،احتوت على (أبنية الأسماء المجردة الرباعية والخماسية، وأبنية

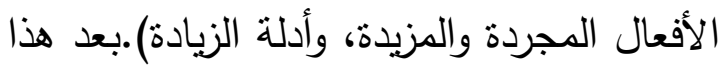
كله رأيتُ أن أثنارك في تحقيق هذا الكتاب، فقمتُ بتحقيق سبع لوحات نالية للوحات المحققة السابقة، وهي متعلقة بمواضع حروف الزيادة. وقد اعتمدت في تحقيقها على المنهج العلمي

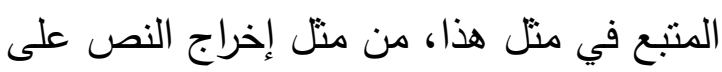

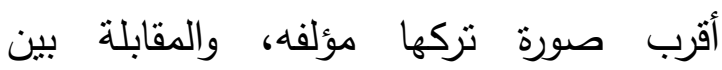

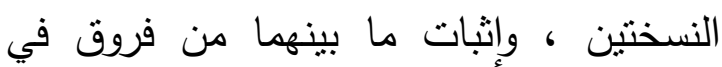
الهامش ، وما إلى ذلك مما لا حاجة لتكرار ذكره هنا. واله أسأل أن يكرمنا بما قد عزمنا

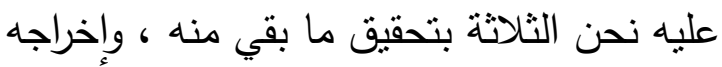
كاملا لمحبي العربية .

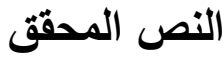

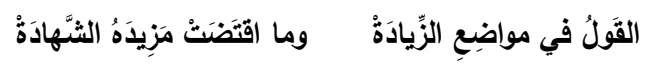


الزيادةَ لا تكونُ إلا مِنها(ْ). وليس المرادُ أنّها تكونُ

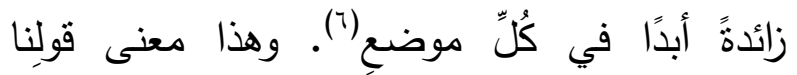

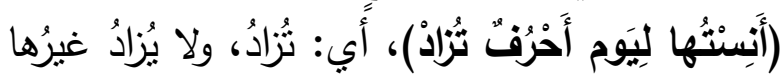

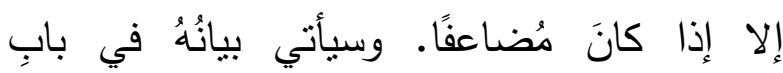
المُضاعفِ إن شاءَ اللهُ.

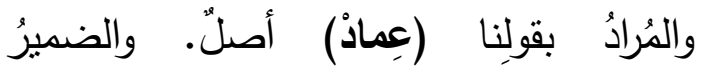
المُضافُ إليهِ غيرُ عائدٍ على حروفِ (أَنِنتُُها

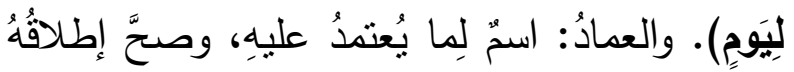

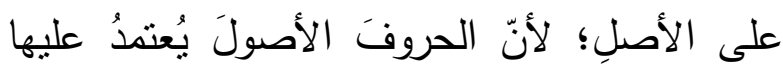
في بناءِ الكلمِة.

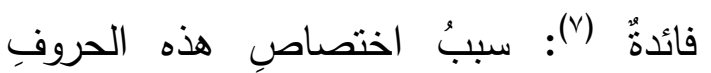

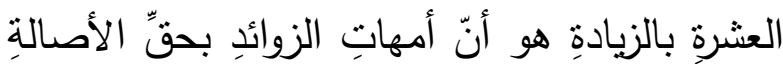

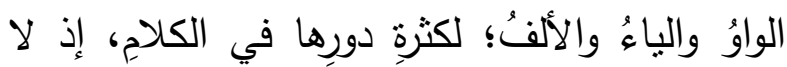

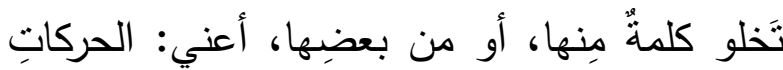

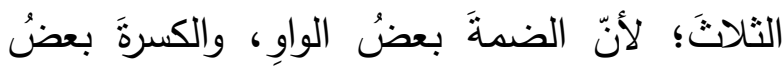

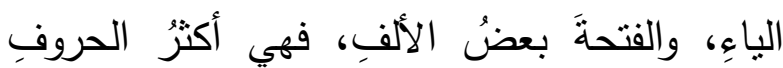
زيادةً على ما سيتنيّنُ في فصولِهِا إن شاءَ اللهُ.

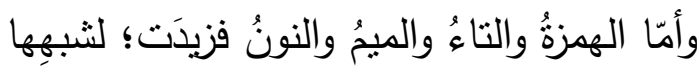

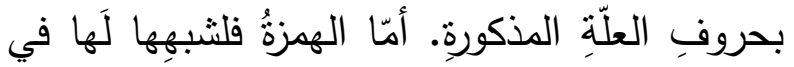
التغيير بالتسهيلِ والحذفِ والبدلِ. وأمّا التاءُ فلثبهِهـا

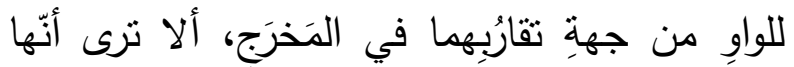

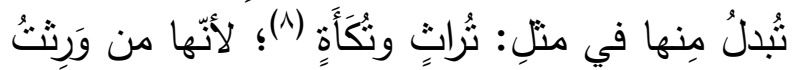

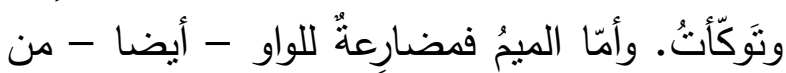

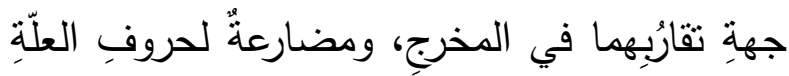

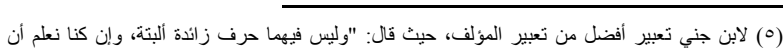
الهمزة و الواو و الياء من حروف الزيادة في غير هذا الموضع". المنصف (19/9 (9).

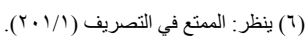

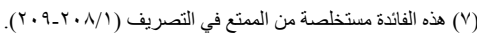

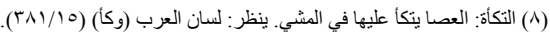

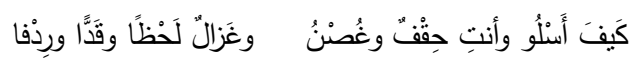

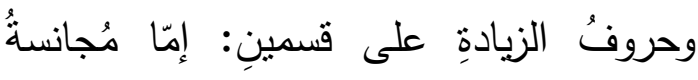

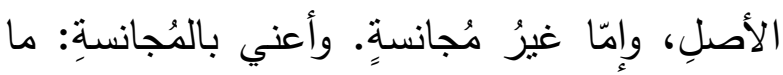

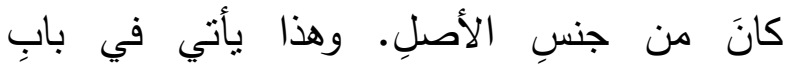

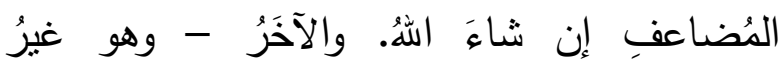

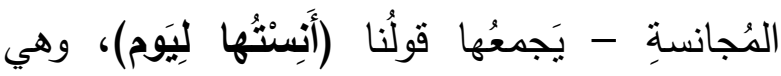
عشرةُ، وجمعَها علماءُ هذا الفنّ نظما ونثرا في صُوَرِ

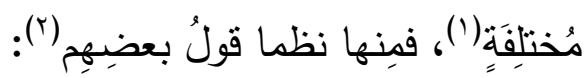

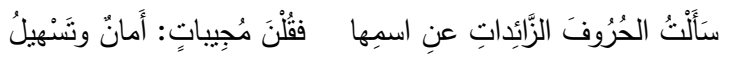
وقال أبو الفتح ابنُ جنّي في المُنصفِ(َ):حُكي

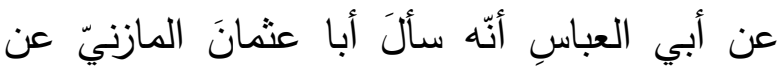

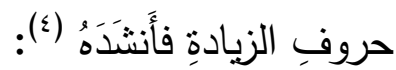

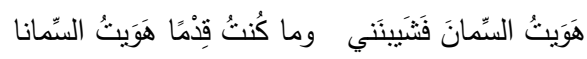

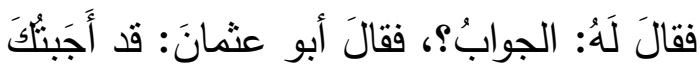

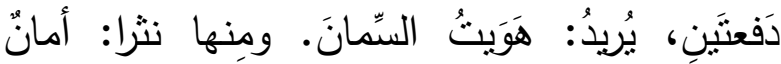

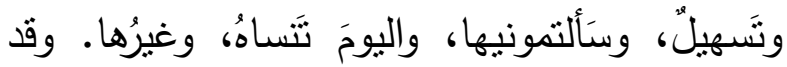

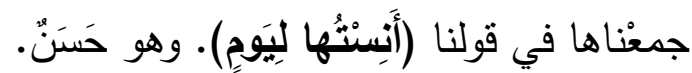
وسُمِيَت هذه الحروفُ بحروفِ الزيادةِ، وإن

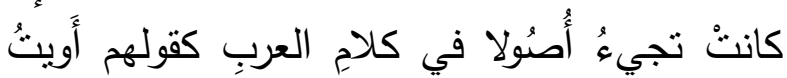

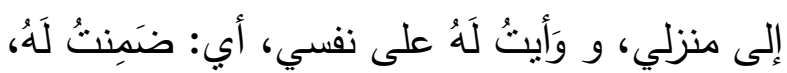

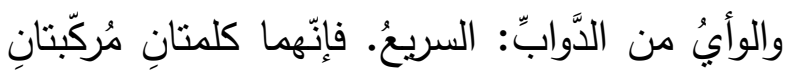

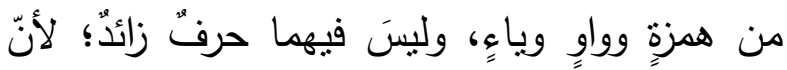

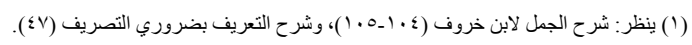

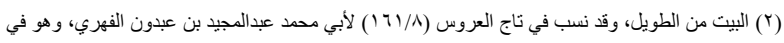

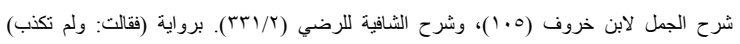
و و(قالت: ولم تبخل).

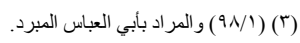

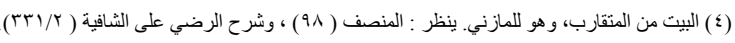




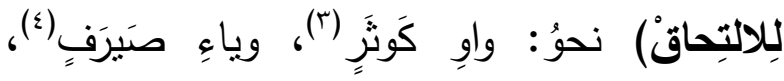

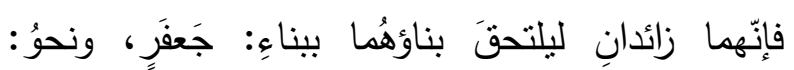

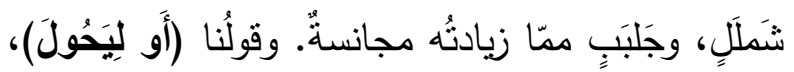

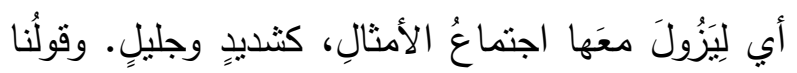

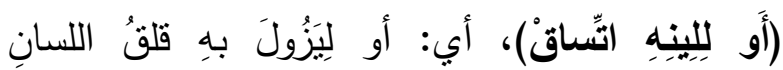

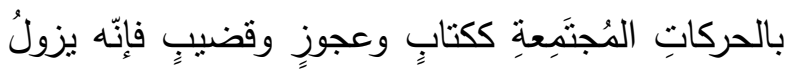

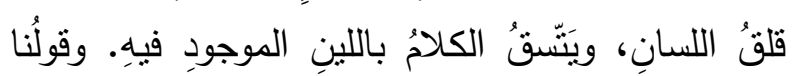

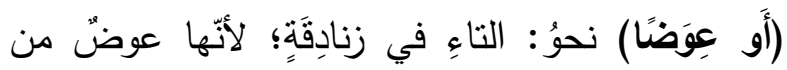

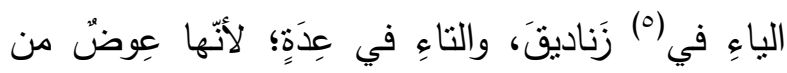

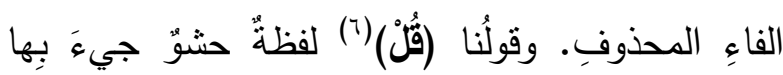

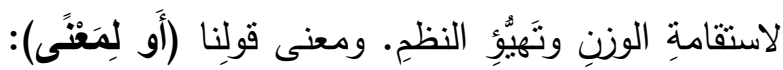
أو لأجلِ بيانِ معنَى، كحروفِ المضارعةِ، وياءِ

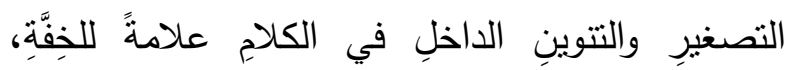

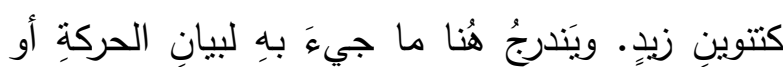

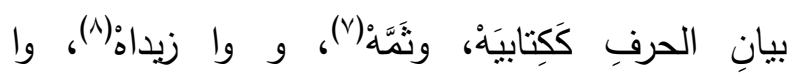

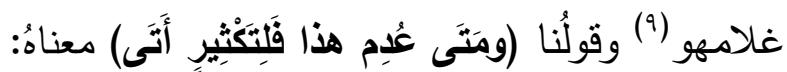

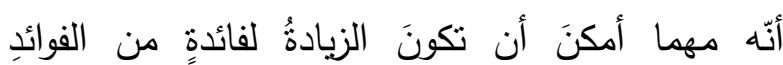

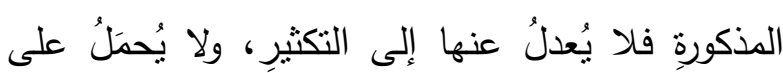

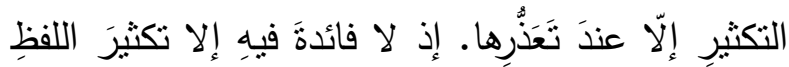

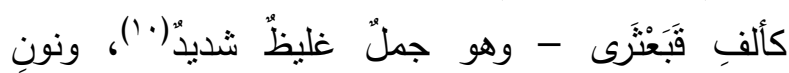

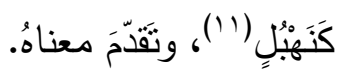

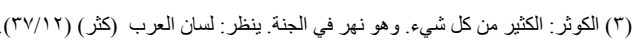

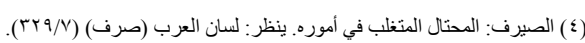

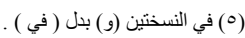
(7) في النسختين (قل أو لمعنى) بزيادة (أو لمعنى) سهو من الناسخ.

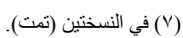

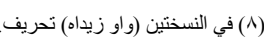

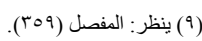

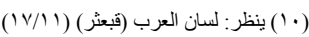

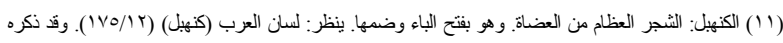

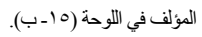

كلّّها من جهةِ الغنّة فيها الثبيهةِ باللين الذي في

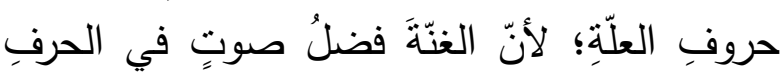

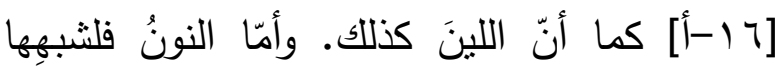

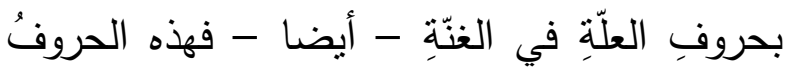

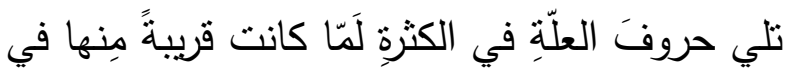

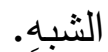

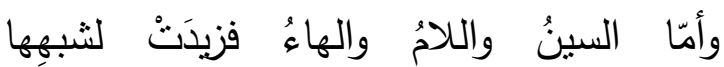

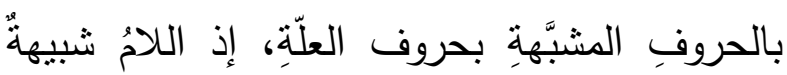
بالنونِ في الاستطالةِ في المخرَج على ما نَعلمُ في

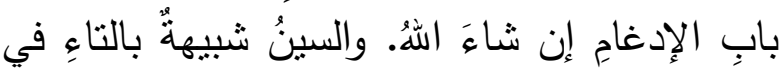

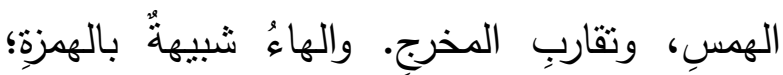
لنقارُبِ مخرجِها؛ لأنّهما من حروفِ الحلقِ.

وهذه الحروفُ مزيدةُ في ألفاظٍ مسموعةٍ لا لا

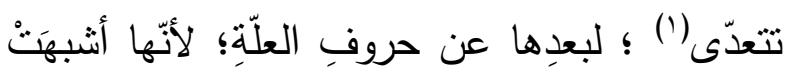

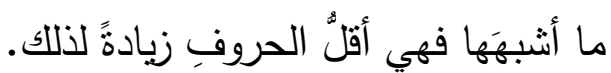

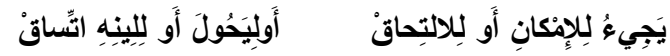

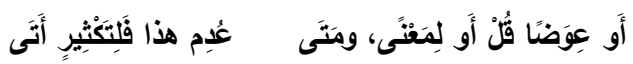

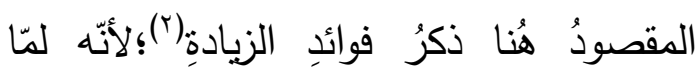
ذكرْنا حروفَها استدعى ذلك معرفة فوائدِها، ونتشوّقتِ

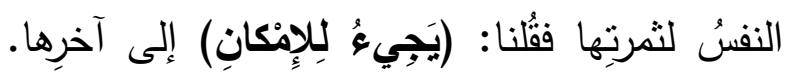

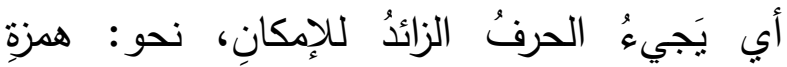

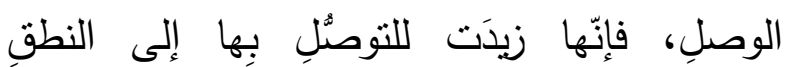

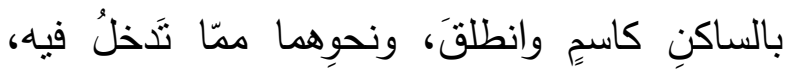

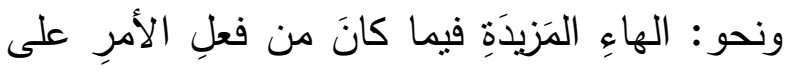

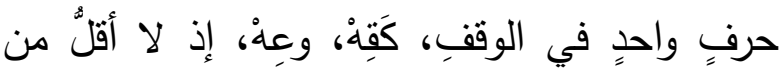

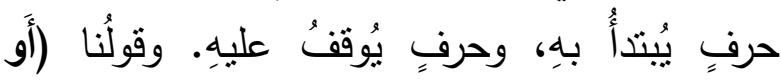


حروفِ العلّةِ. فلا جرمَ انحصرَ قصدُنا في عثرةٍ

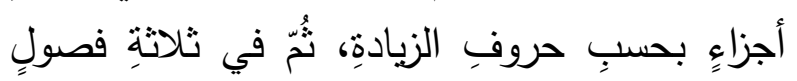

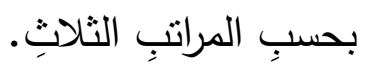

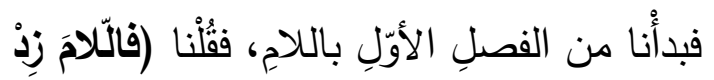

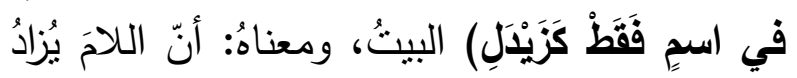

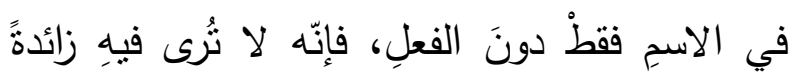

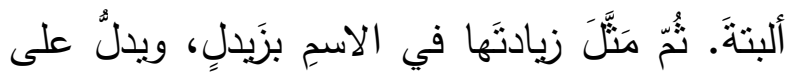

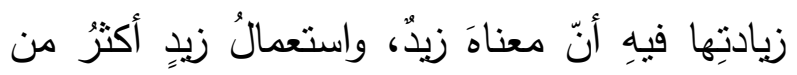

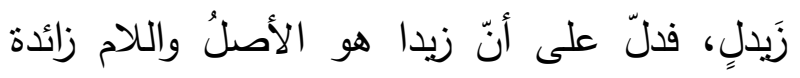
عملا بالنظيرِ • وبَندرجُ في النتبيهِ سائرُ الألفاظٍ

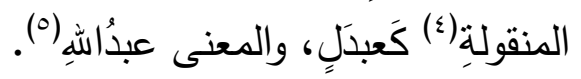

كما قالوا في عبدالدارِ : عَبَربيٌ، وفي عبدقيسٍ:

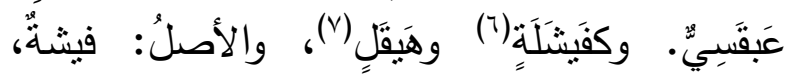
وهيقُ ().

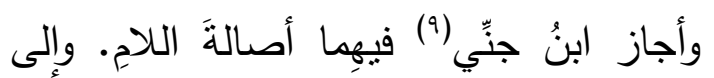

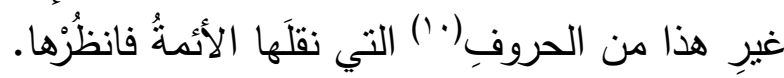

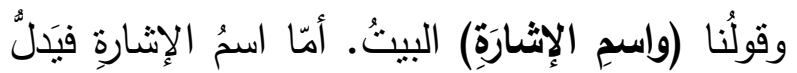

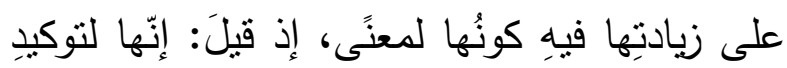

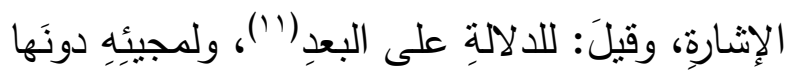

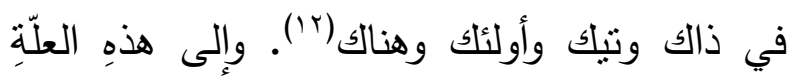

( ) أي: الأسماء المنقولة إلى العلمية.

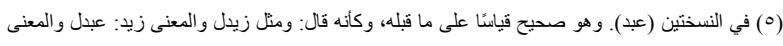

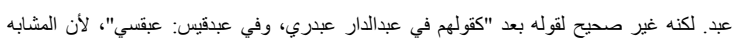

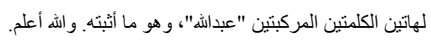

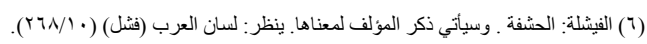

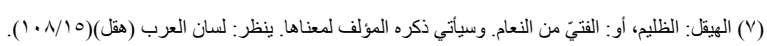
(^) لم بعتمد المؤلف هنا على كلام ابن عصفور ؛ لأن ابن عصفور جعل زيادة الثلام في هاتين الكلمتين محتملة.

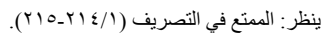

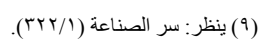
(·) (1) يعني بالحروف الكلمات. ومن هذه الكلمات: طيسل وفحجل وقلفع وعقرطل و عثول وازلغب و وادلهّ.

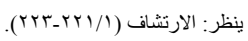

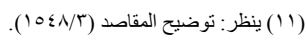

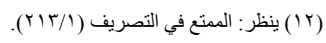

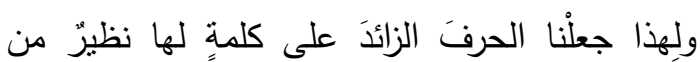
الأصولِ في كلمةٍ أُخرى للإِحاقِ هروبًا (') مِن عدمِ الفائدةِ.

فائدةُّ(؟): يُعلمُ أنّ الحرفَ الزائدَ في الإلحاقِ

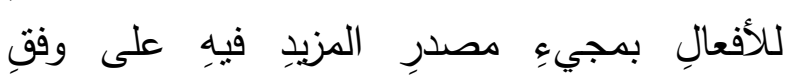
مصدرِ [ب (ا-ب] المُلحقِ بهِه، وقد تقدَّمَ في أبنيةِ الأفعالِ(r)، وفي الأسماءِ بمجيئِهِ في مُقابلةِ حرفٍ أصليِّ من بناءٍ آخرَ ، وعلى وفقِ بنائِِه إلا في خمسةِ

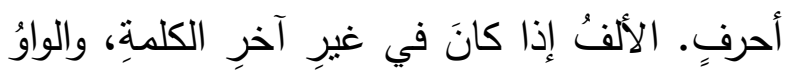

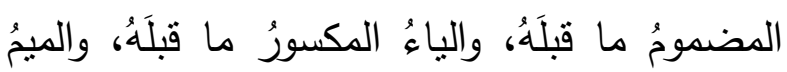
والهمزةُ في أوّلِ الكلمةِ. فأمّا الألفُ فلم يُّحَق حشَّا لكلمة أصلا. وأمّا الواوُ والياءُ بشرطِهما فذلك حملا على الألفِ بجامِ الاعتلالِِ والمدِّ كََضيبٍٍ وعَجوزٍ .

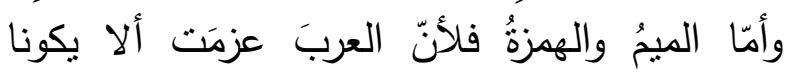
أصلينِ هناك، واستعمالُهما للإِحاقِ تقريبُ الأصلِ،

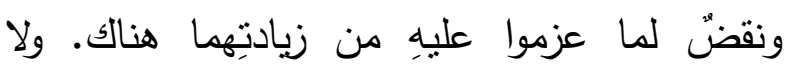
بُعترضُ بما شذّ، وجاء فيه أصلا منهُما؛ لخروجِها عن الأصلِ.

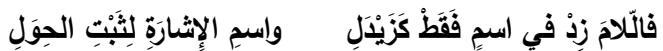

لما فرغْنا من حروفِ الزبادةِة وما بَتعلَّقُ بِها من ذِكرِ فوائدِ الزيادةِ قصدْنا إلى الأماكنِ التي تَطَّردُ

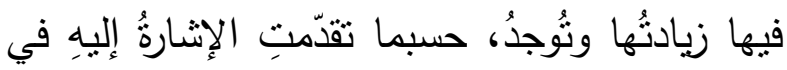

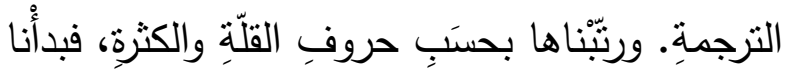

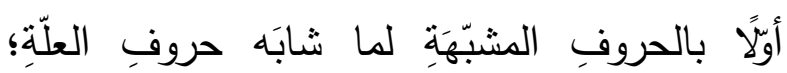

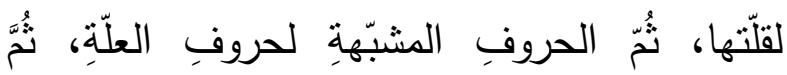

(1) (1) كلمة (هروبا ) غير واضحة في النسختين.

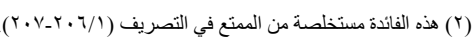

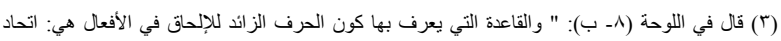

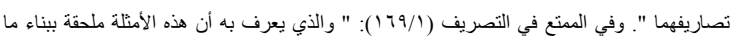
ذكرنا مجيء مصادر ها على حسب مصادر ما ألحقت به ". 
زيََت فيهِ لبيان حرفِ المدِّ نحو: وَا زيداه ". وجاءَ

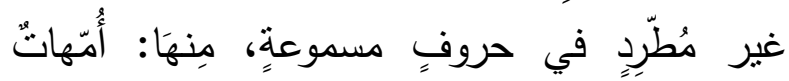

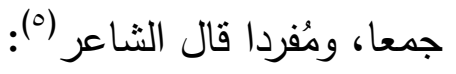

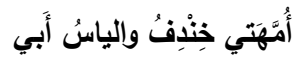

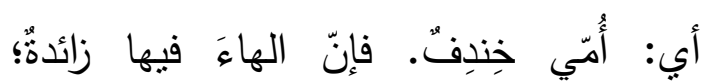

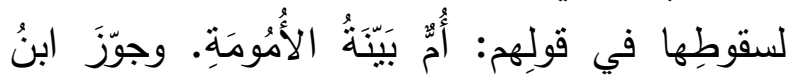

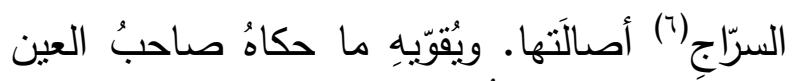

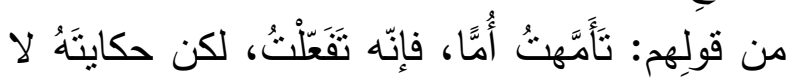

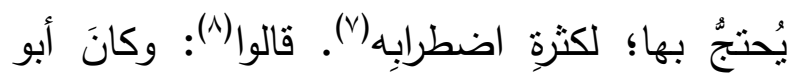

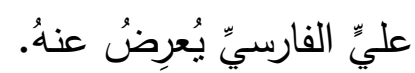

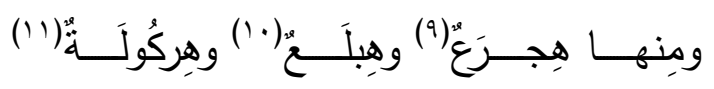

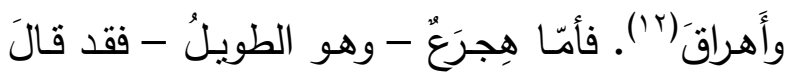

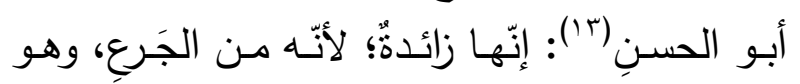

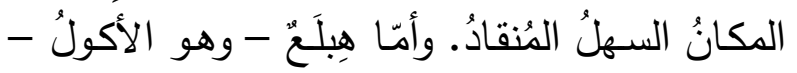

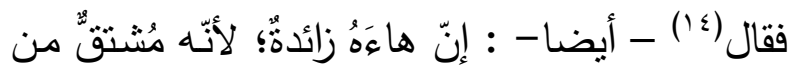

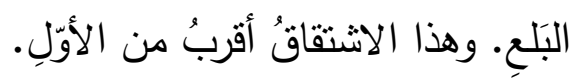

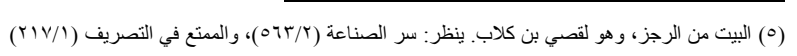

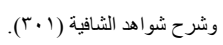

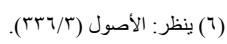

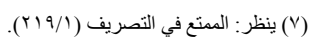

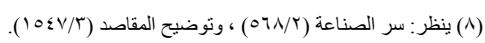

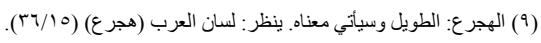

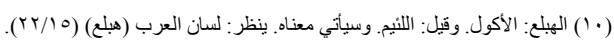
(') الهركولة: الحسن الجس، وقيل: الضخمة الأوراك. وسيأتي معناها. ينظر: لسان العرب (هركل) .$(1 \cdot / 10)$

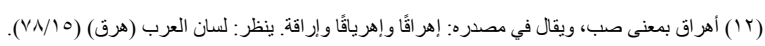

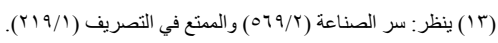
( ) (1) ينظر: المصدر ان السابقان.
وقعَتِ الإشارةُ بقولِنا (لَتَبَتِ الحِوَلِ)، أي: لتحوّلِها عن حالةِ الثبوتِ إلى حالِّة السقوطِ مع بقاءِ المعنى.

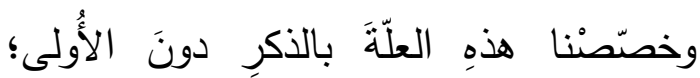

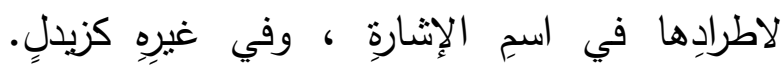

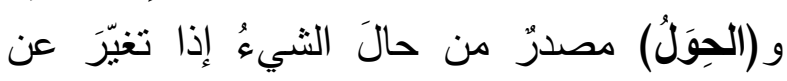

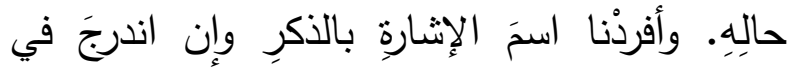

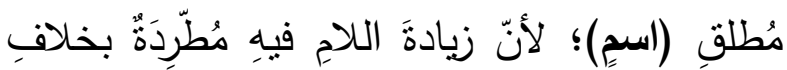

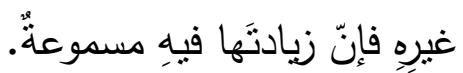

تَحصيلُ (')زيادةُ اللامج على ضربينِ: زيادتها

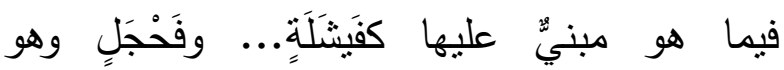

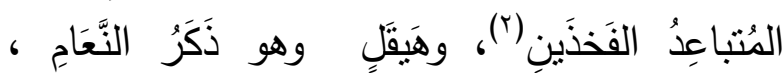

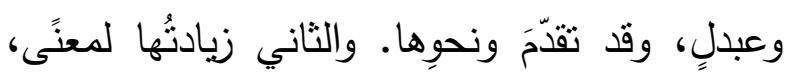

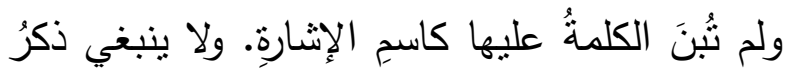

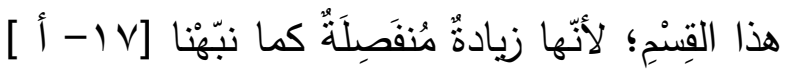

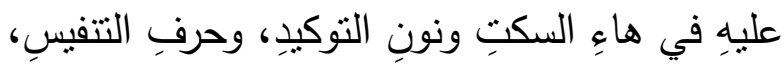

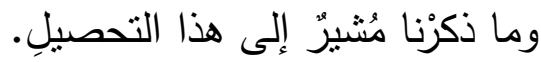

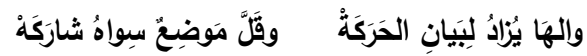

كأثنرْنا هُنا إلىى الجُزءء الثاني من الفصلِ الأوّلِ.

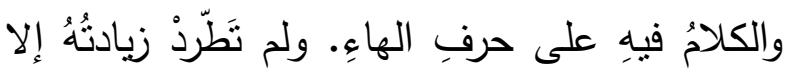

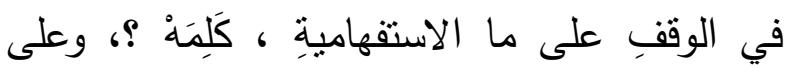

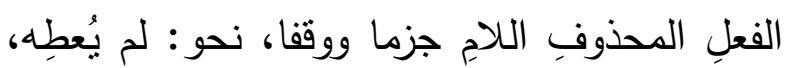

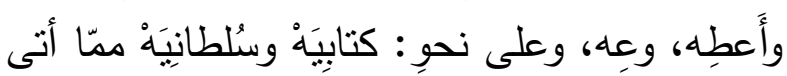

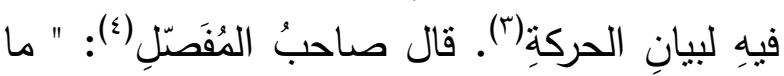

(1) هذا التحصيل مستفاد من توضيح المقاصد (r/ 1 (1 1) ).

( (ץ) ينظر : لسان العرب (فحج) (• (191/1). (r) ينظر : توضيح المقاصد (T/ (T) 10 (1).

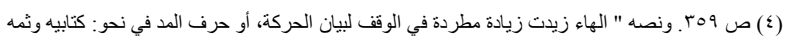
و وازيداه و وا غلاماه و وا غلامهوه". 
صاحبُ المُفصَّلِ -؛ لكونِهِ في بيانِ الحرفِ زيادةً

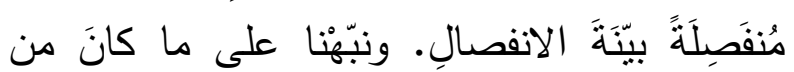

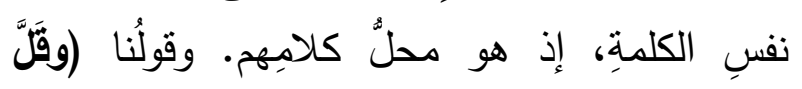

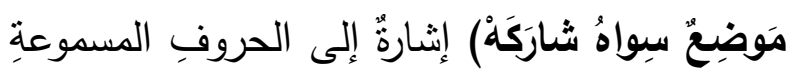
التي ذكرنا بعضَها، ونحوَها مدّا عسى أن يَتَذَّ عمّا

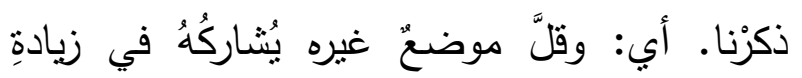

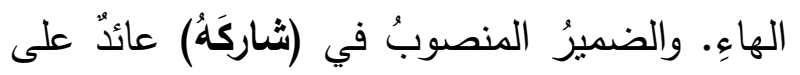
ما زيدَ فيهِ لبيانِ الحركةِ.

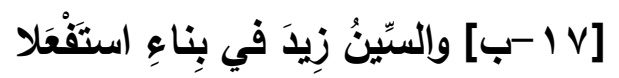

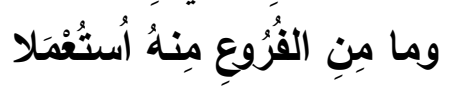

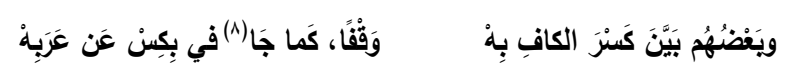

هذا هو الجزءُ الثالثُ في حرفِ السينِ، وبِه

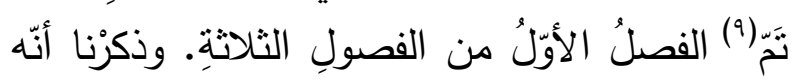

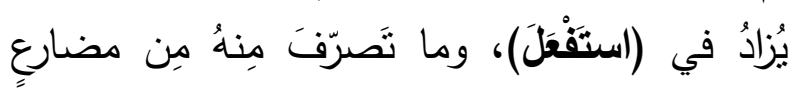

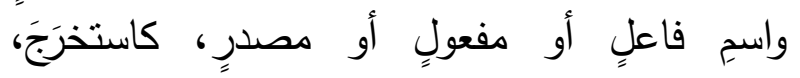

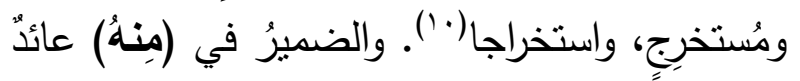
على بناءٍِ (استَفْعَل). وهذا معنى البيتِ الأوّلِّ.

وأمّا الثاني فمعناهُ أنّ بعضَ العربِ(1') زادَ

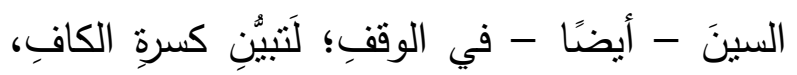

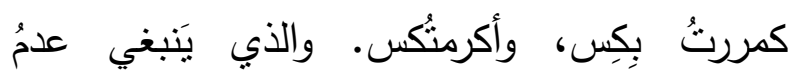

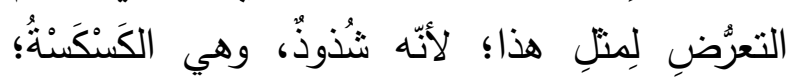

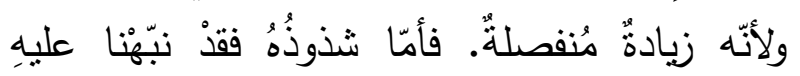

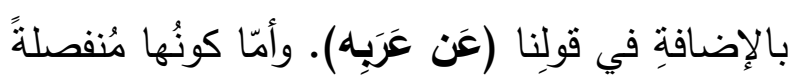

(^) في النسختين (جاء) بالتحقيق، و لا بستقيم به الوزن.

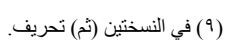

(·) (1) في النسختين (استخرجا).

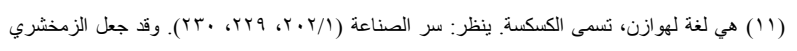

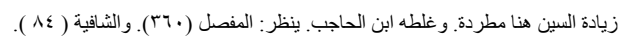

وأمّا هِركُولَةٌّه فقالَ الخليلُ (1): الهاءُ فيها زائدةٌ؛

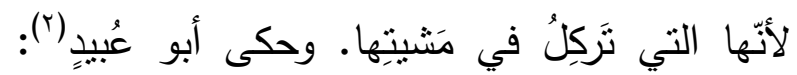

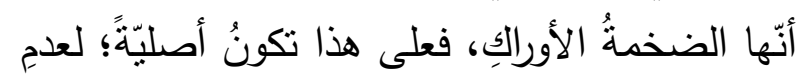
ما يَقضي بالزيادةِ.

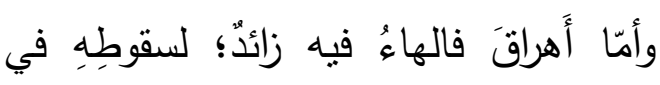

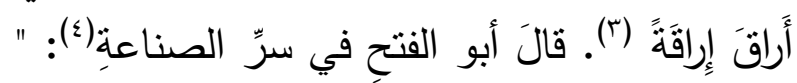

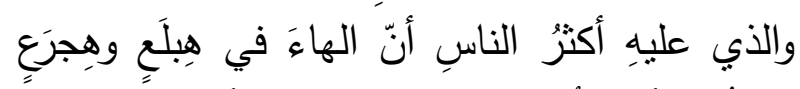

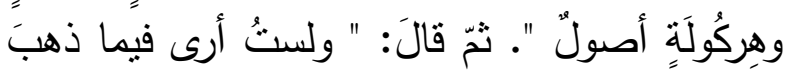

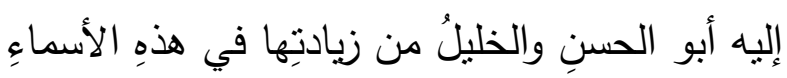

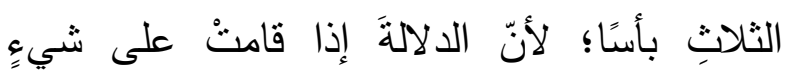

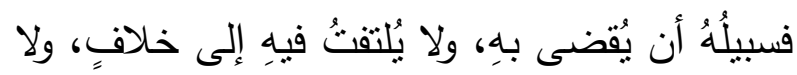

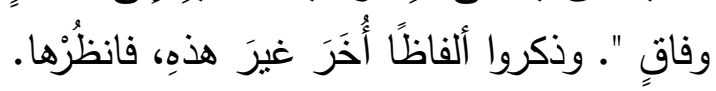

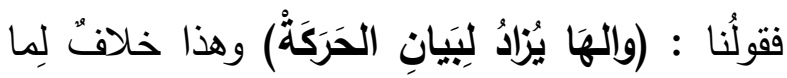

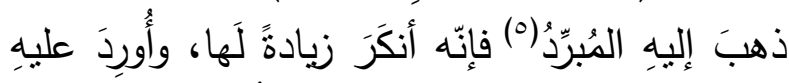

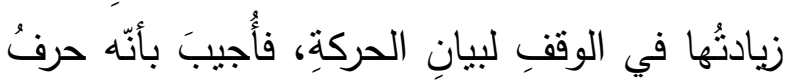

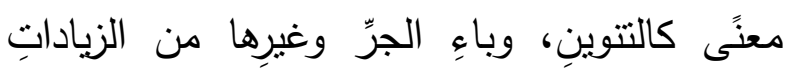

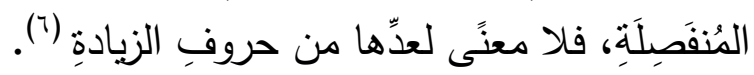
والصحيحُ الأوّلُ؛ لنثبوتِ زيادتِهِ، وإِن كانت

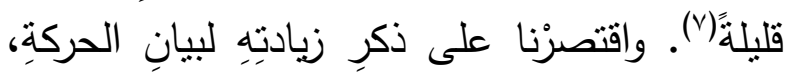
ولم نَذكُز زيادتَها لبيانِ الحرفِ - كما أَثْارَ إليهِ

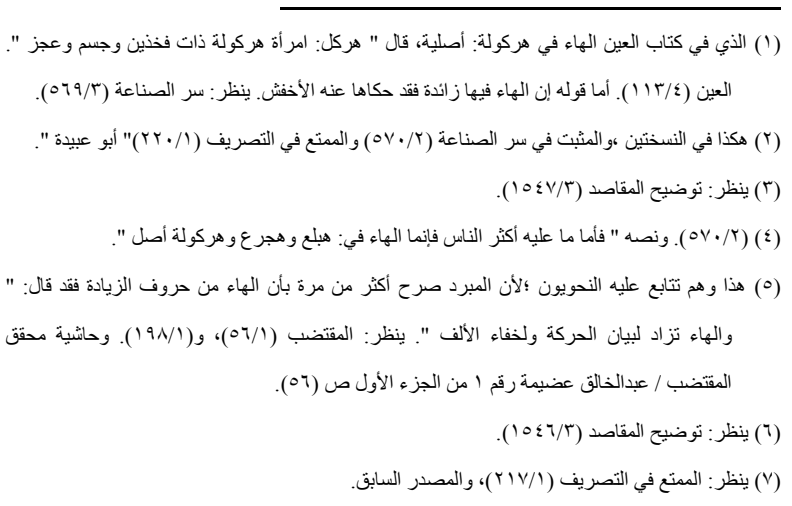




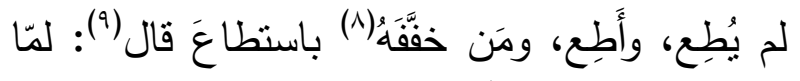

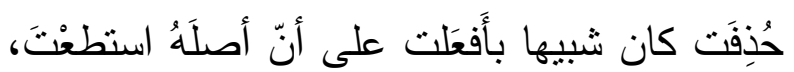

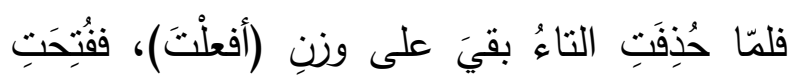

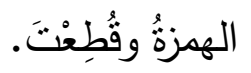

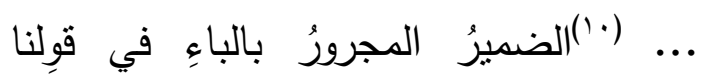

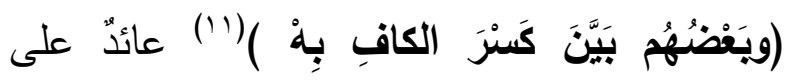

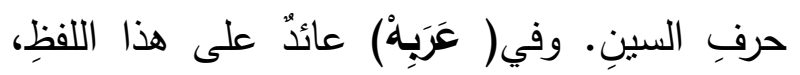

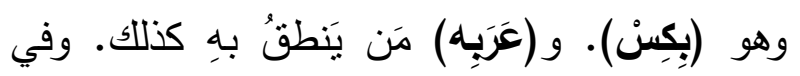

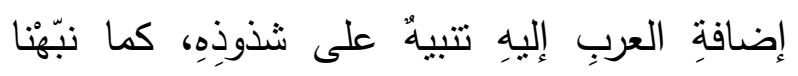

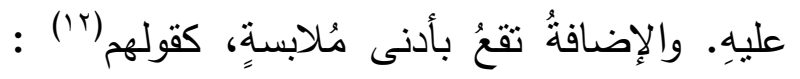

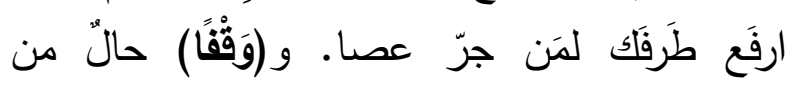
الفاعلِ بـ(بَيّن).

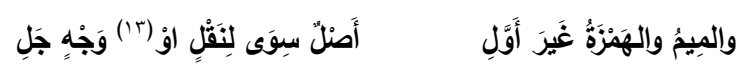

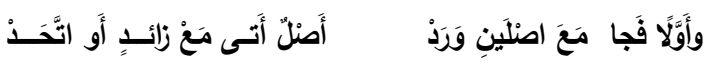

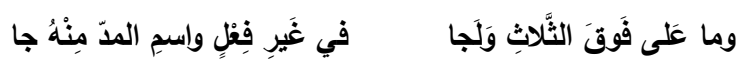

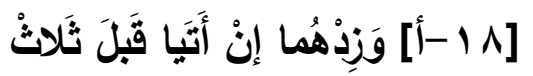

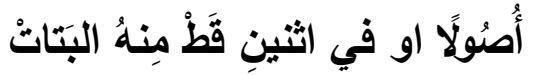

هذا هو الفصلُ الثاني في الحروفِ المُشبّهَةِة

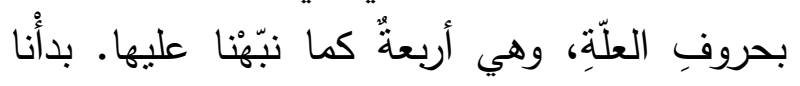

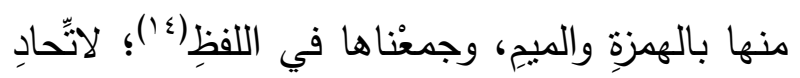

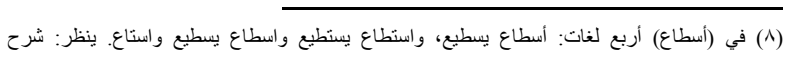

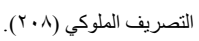

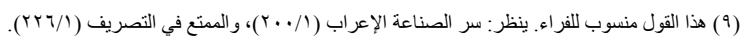

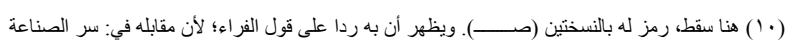

والمتع في التصريف: وهذا غير مرضي؛ لأنه لا موجب لقطع الهمزة بعد أن كان الاطر اد بوصلها.

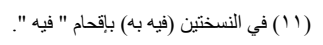

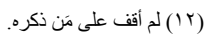

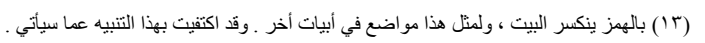

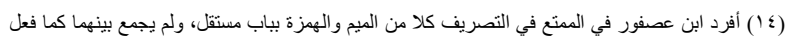

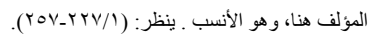

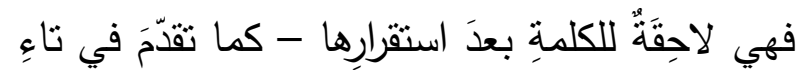
الثانيةِ (1) ، ونحوهِا.

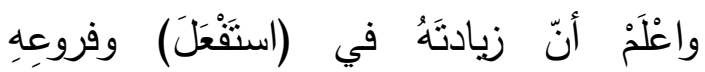

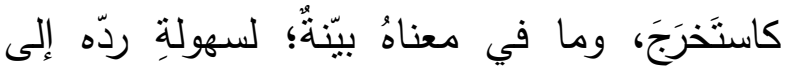

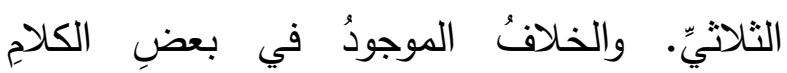

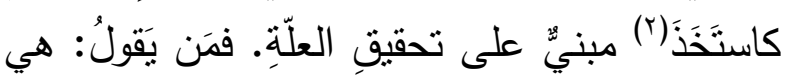

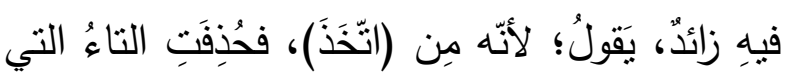

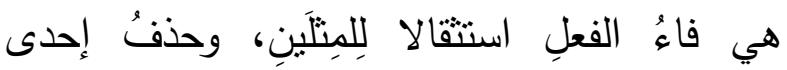

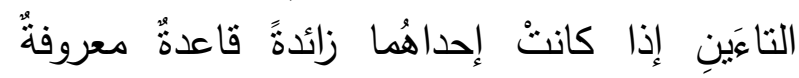

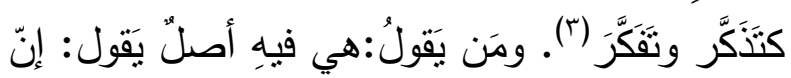

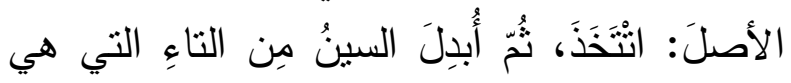

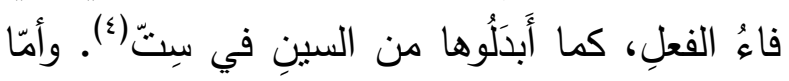

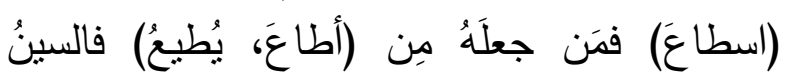

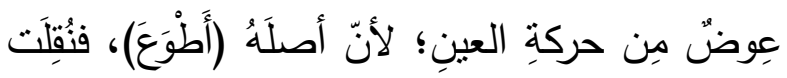

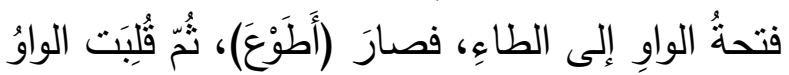

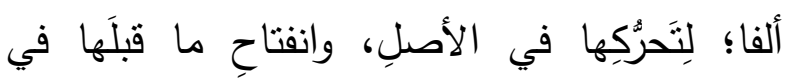

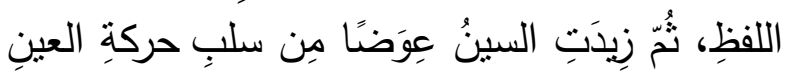

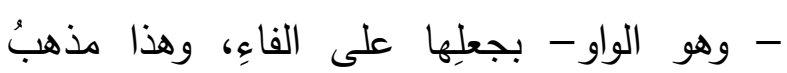

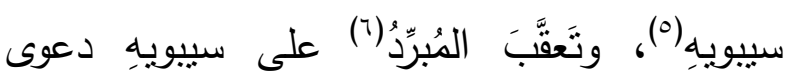

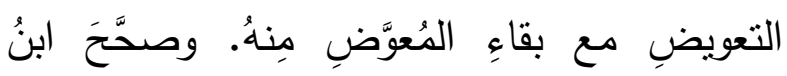

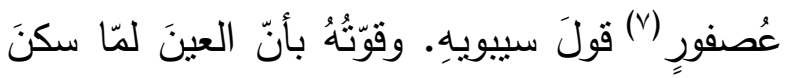

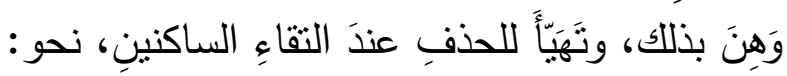

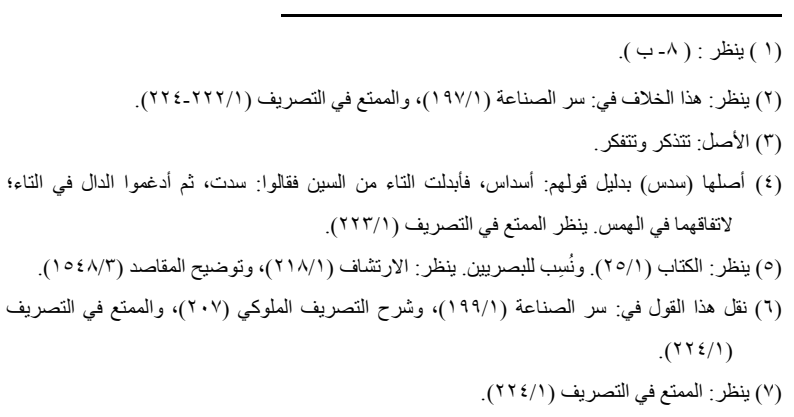




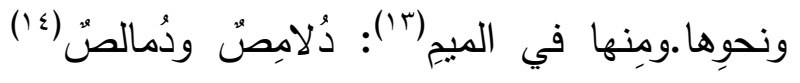

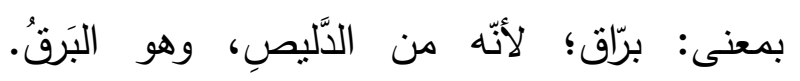

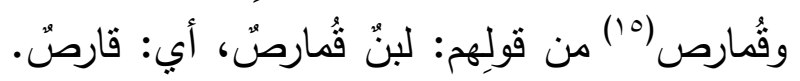

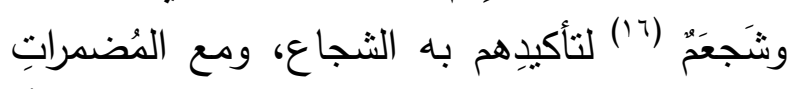

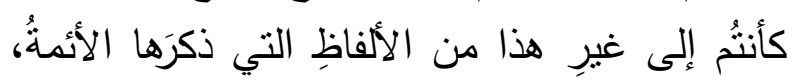
وهي محصورةٌ.

و (غيرُ) في قولنِا (غيرَ أوّلِ) حالّ من الميح

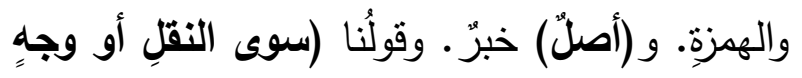
جَلي) (lv) الإشارةُ بالاستثناءِ إلى أمرين:

أحدهما: ما ذكرنا من المواضعِ التي قامَ الدليلُ على

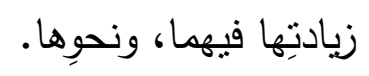

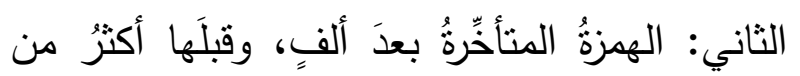

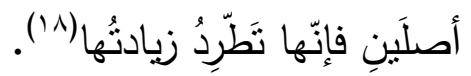

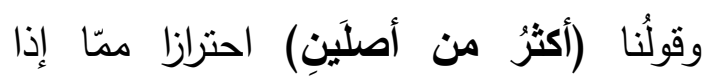

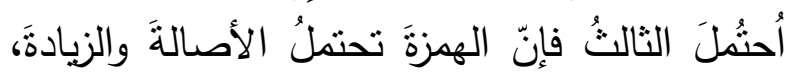

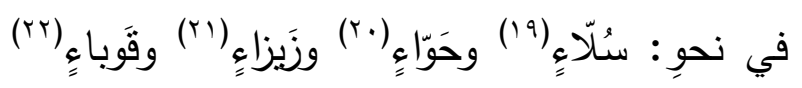

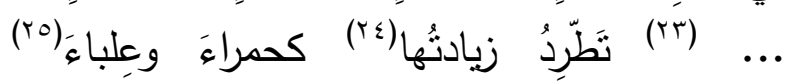

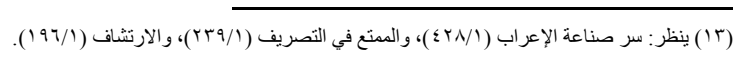

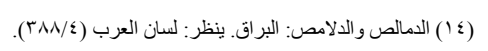

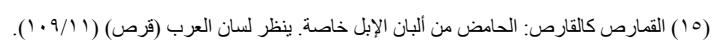

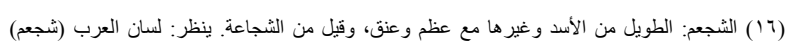
$(\Upsilon \wedge / \mathrm{V})$

( IV)

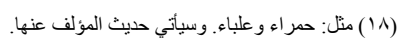

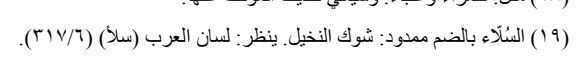

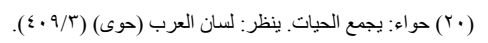

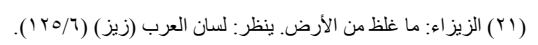

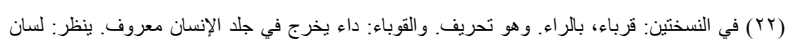

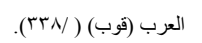

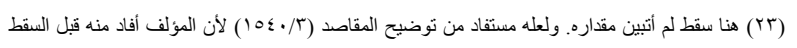
وبعده.

(Y (Y) مر اده هنا أن الهزة إذا وقعت بعد ألفٍ قبل الألف أكثر من حرفين فإنها تكون زائدة باطر اد.

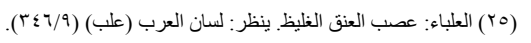

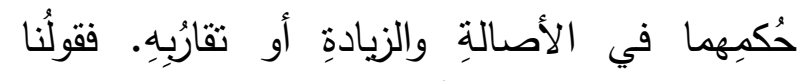

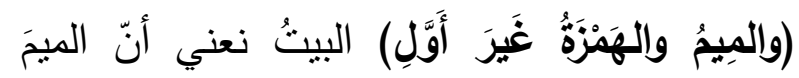

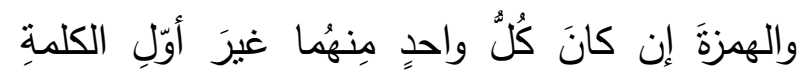

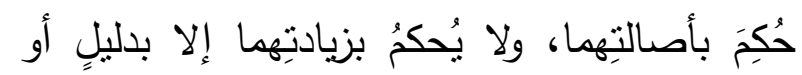

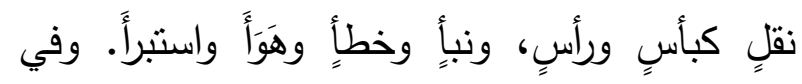

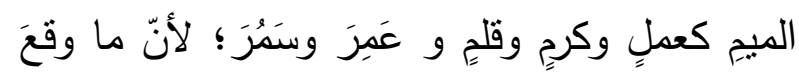

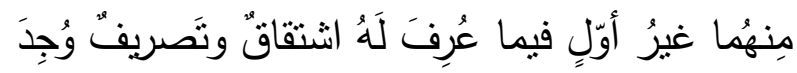

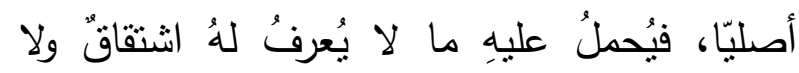

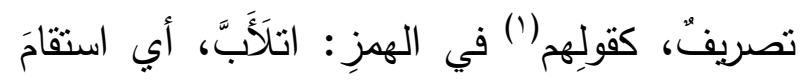

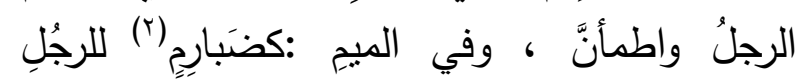

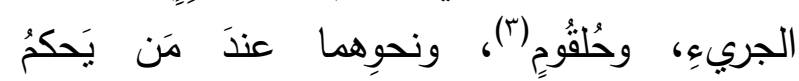

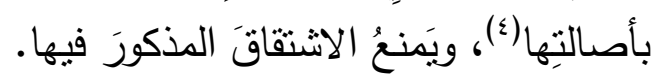

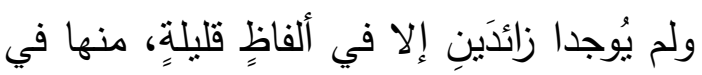

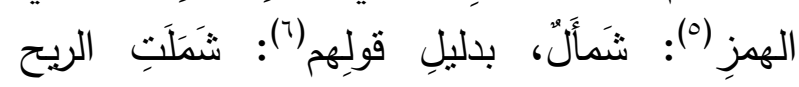

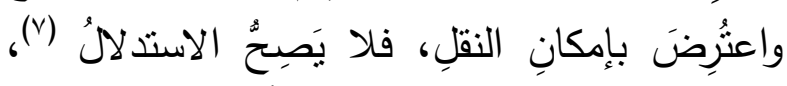

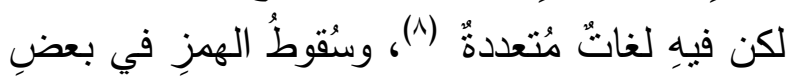

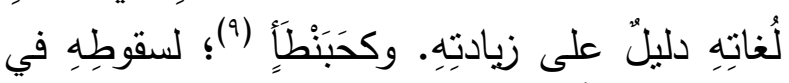

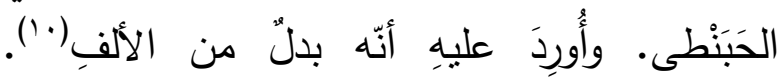

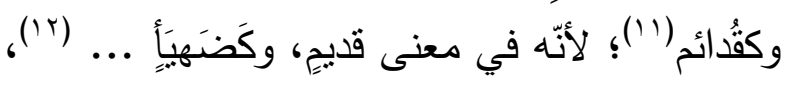

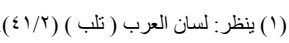

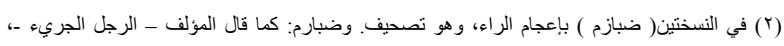

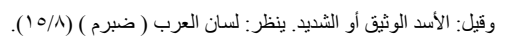

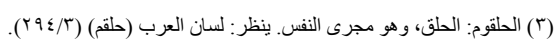

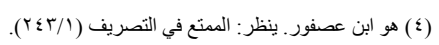

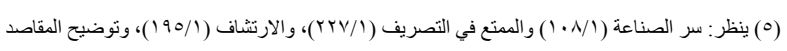

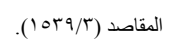

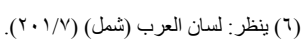

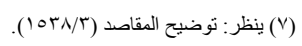

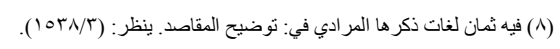

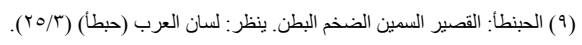

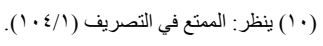

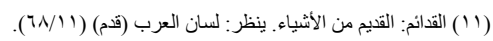

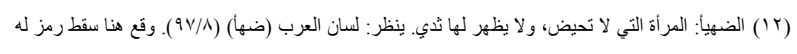

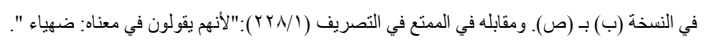




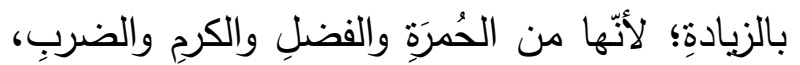

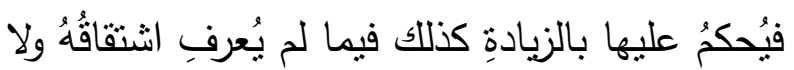

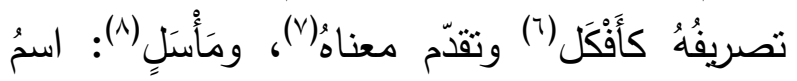

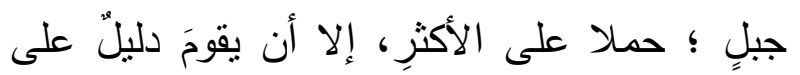

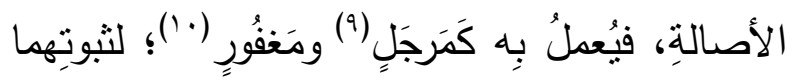
في التصربفِ في قولههم: مَرجَلَ الحائكُ الثوبَ إذا

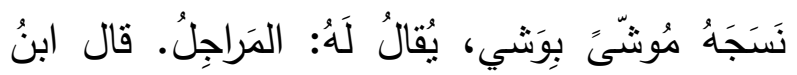

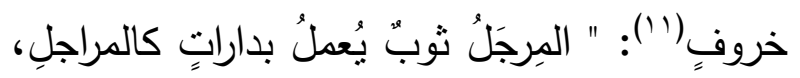

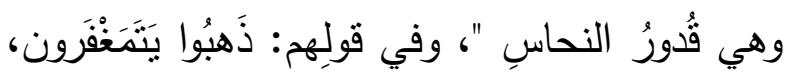

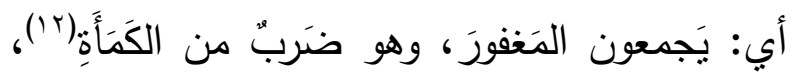
وفيهما خلافُ (r').

وسواءٌ كانت كُلُها أصولا - كما قدّمنتا - أو لم يَكُن منها أصلٌ إلا اثثينِ، واحتملَ الثالثُ فإنَّهُ

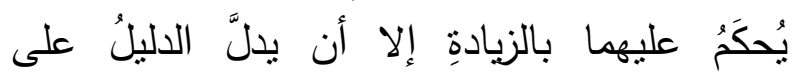

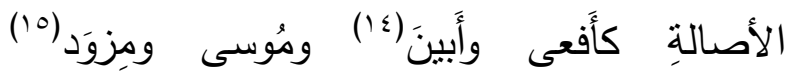

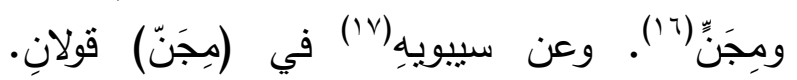

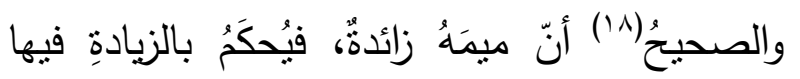

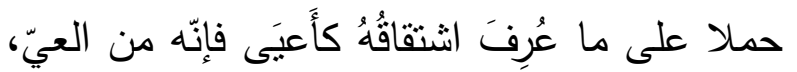

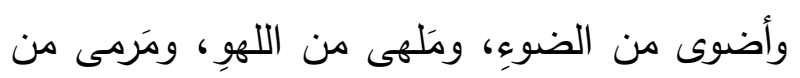

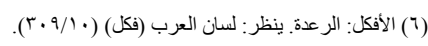

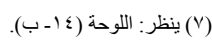

(^) مأسل: اسم جبل - كما قال المؤلف، وقيل: اسم رحلة. ينظر : لسان العرب (أسل) ( / ـ ـ ().

(9) المرجل: القدر من الحجارة والنحاس. ينظر : لسان العرب (رجل) (10 (17 (1).

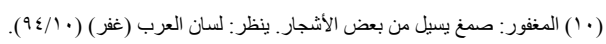

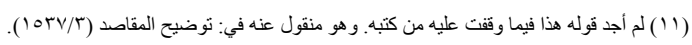

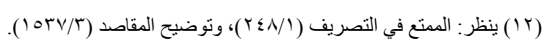

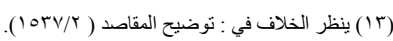

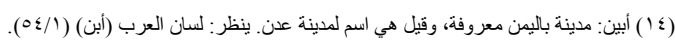

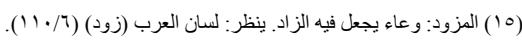

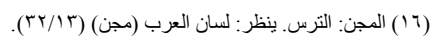

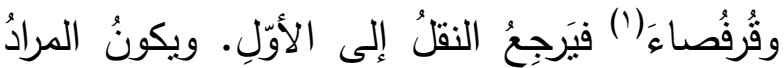

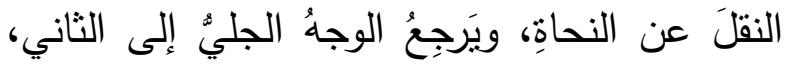

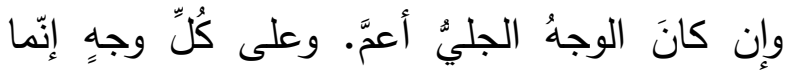

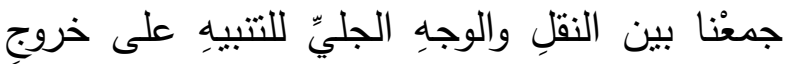
الأمرين، وإن كان في خروجِ الأمرِ الثاني بهذا نظرُ .

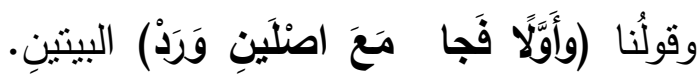

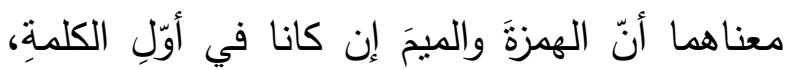

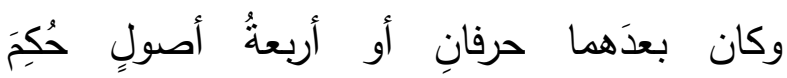
بأصالتِهِها بحسبٍ القيودِ الدذكورة. وبيانُهما أنَّهما إن أن

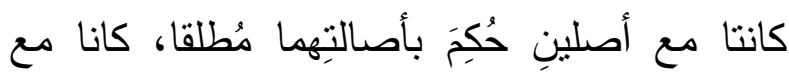

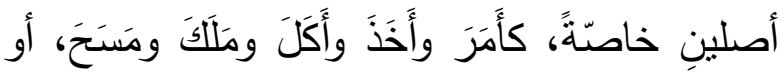

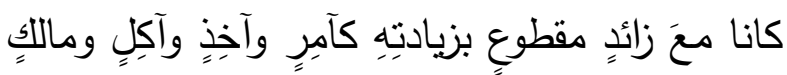

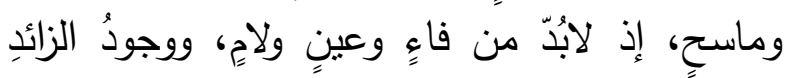

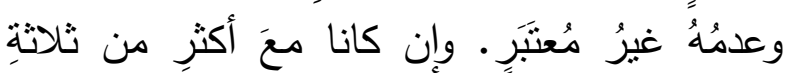

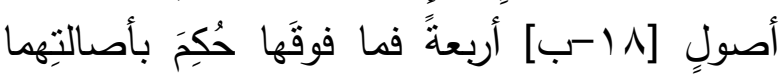

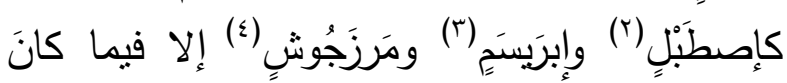
من الأفعالِ أو في الأسماءِ الجاريةِ عليها، فإِّنَّما

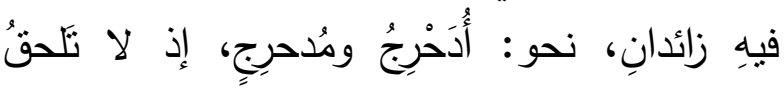

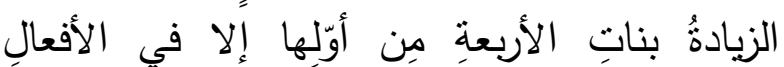
الرباعيّة والأسماءِ الجاريةِ عليها.

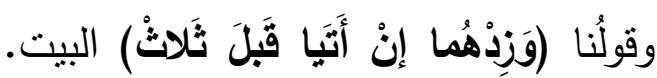

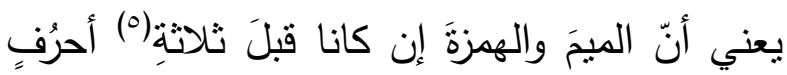

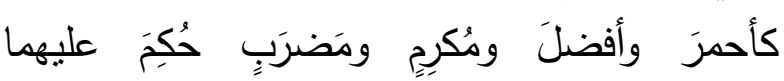

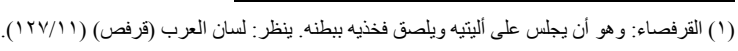

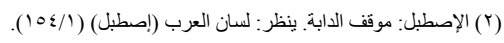

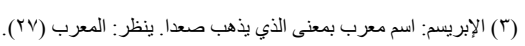

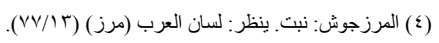

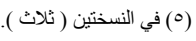


ونونُ النتثيةِ وجمع المذكِِ السالٍِ كالزيدَينِ والزيدِينَ.

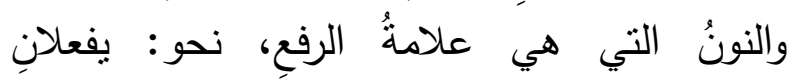
وتفعلون. والنونُ اللاحقة الفعلَ للتأكيدِ، شديدةً كانت فئن

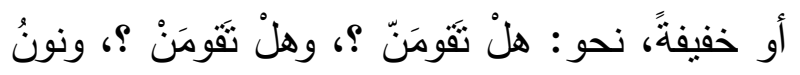

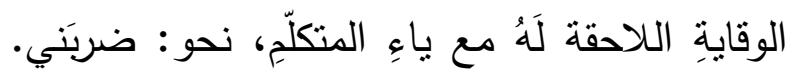

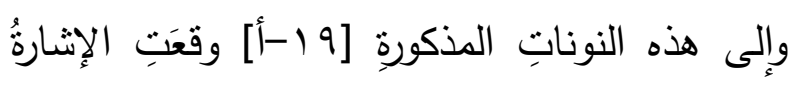
بالبيتينِ.

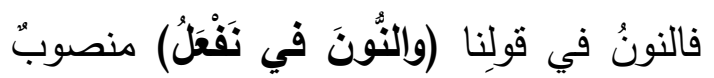

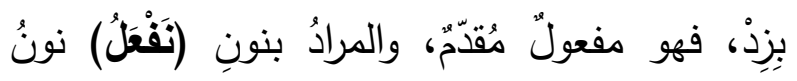

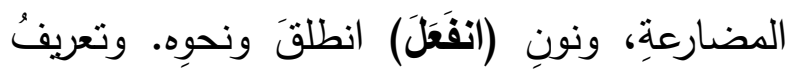

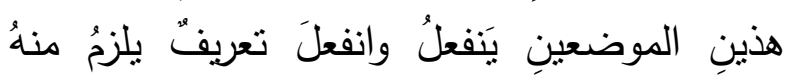

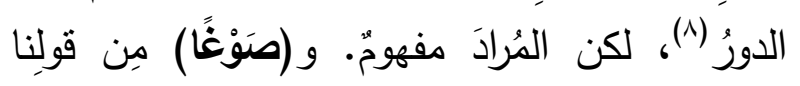

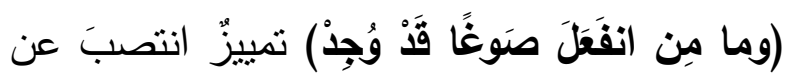

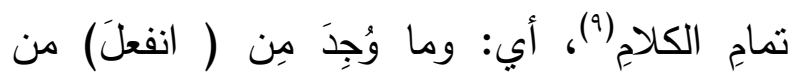

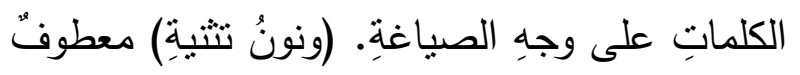

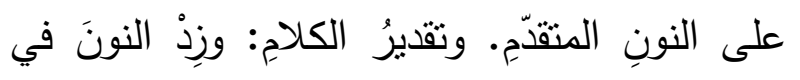

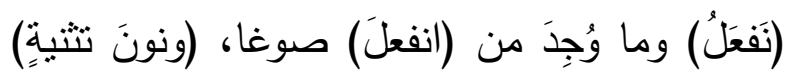

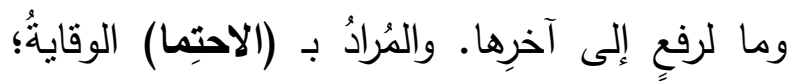

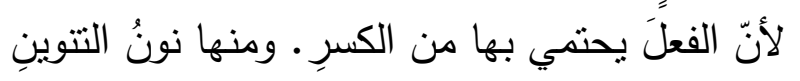

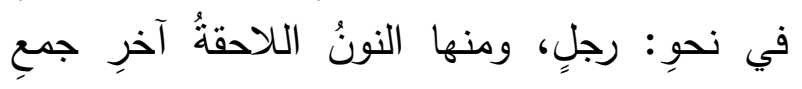

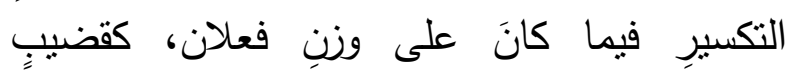

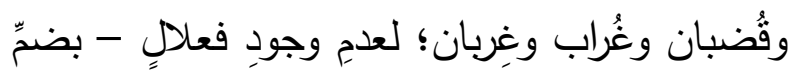

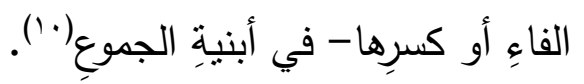

(^) يعرف بالدوران، وهو كما قال ابن جني "أن تودي الصنعة إلى حكم ما، مثله مما يقتضي التنيير فإن أنت

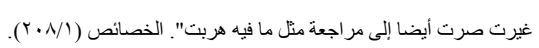

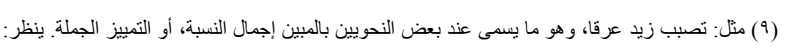

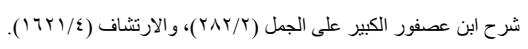

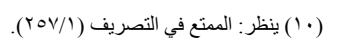

الرمي إلا أن يقومَ دليلّ على الأصالةِ فيهما

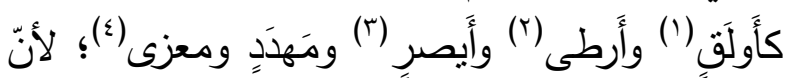

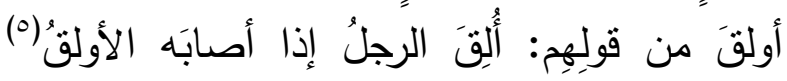

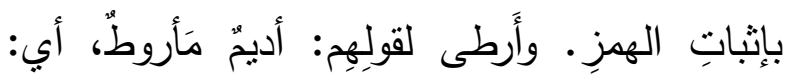

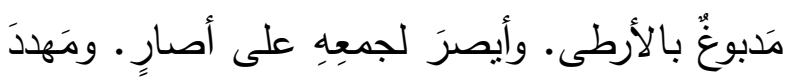

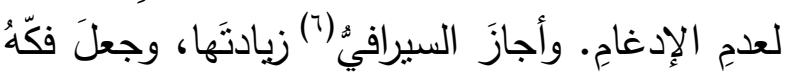

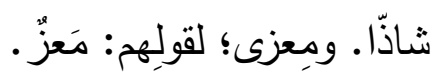

و (البتاتُ) هو القطعُ، أب: قُطِعَ بأصالةِ اثثينِ، ووقعَ الاحتمالُ في الثالثِ. وأمّا المقطوعُ بزيادنِهِ فقدِ

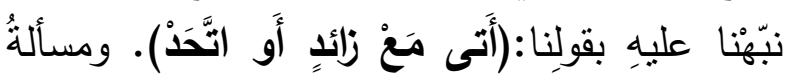

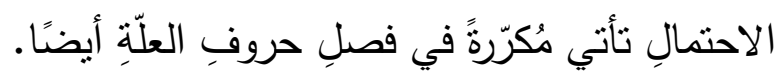

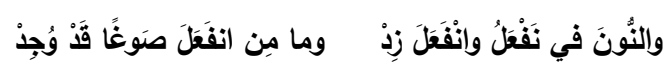

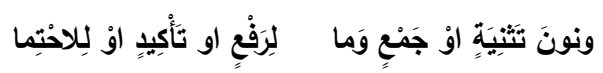
تعرّضنْا هُنا للجزِِ الثالثِ من الفصلِ الثاني،

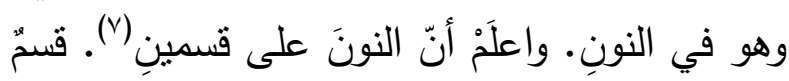

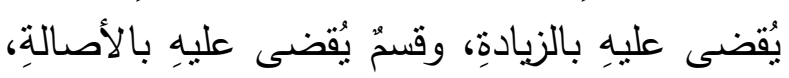

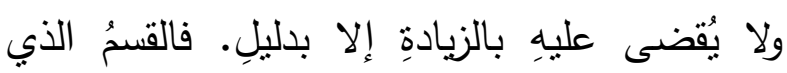

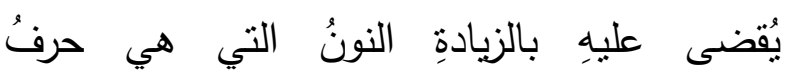

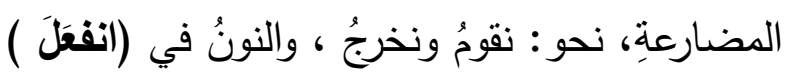
وما تصرّفَ منهُ ، نحو : انطلقَ ومُنطلقِ وانطلاقا.

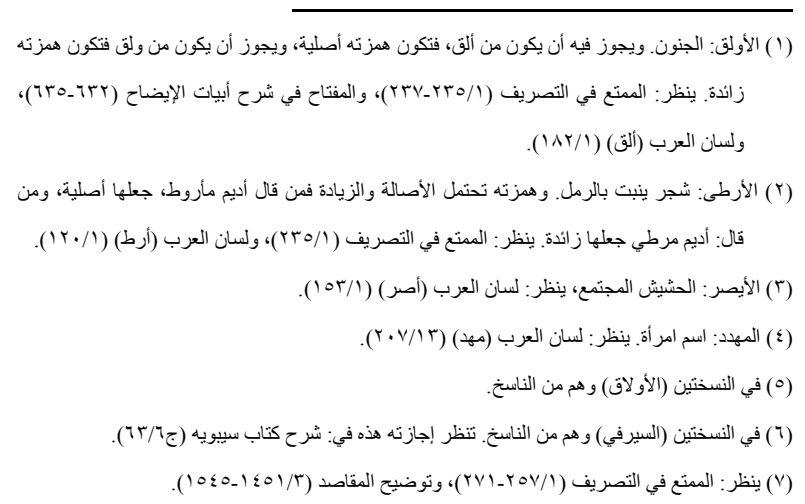


أحدهما: أن يكون ما قبلَ الآخر أكثرَ من

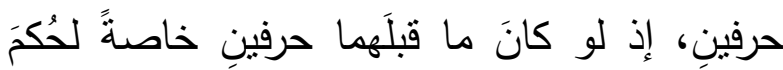

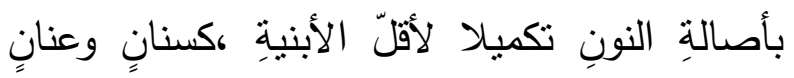
وزمانٍ ومكانٍ.

والثرطُ الثاني ألا تكونَ الكلمةُ من المكرّرِ

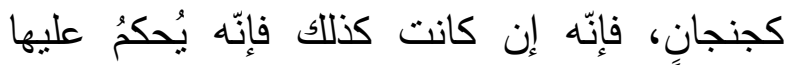

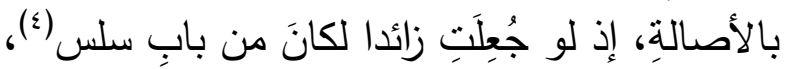
وهو قليله.

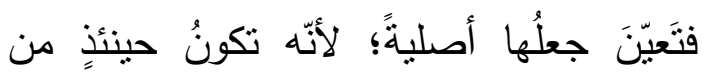

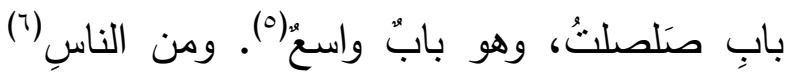

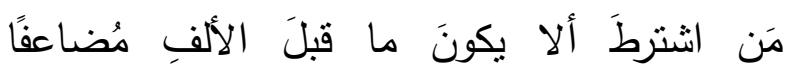

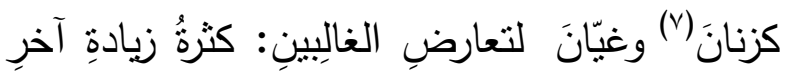

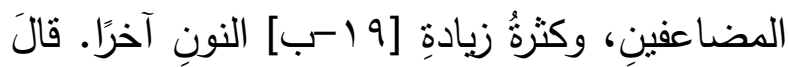

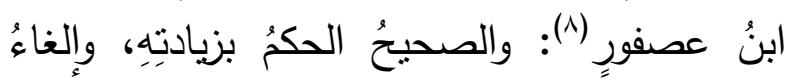

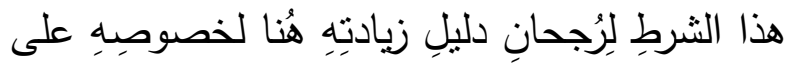

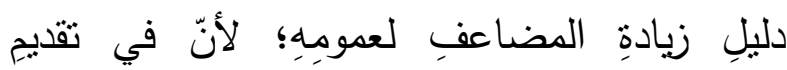

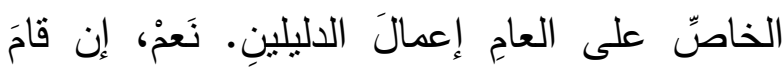

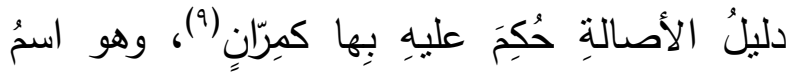

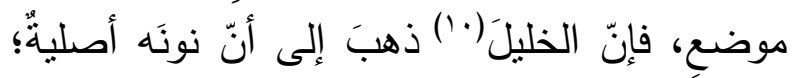

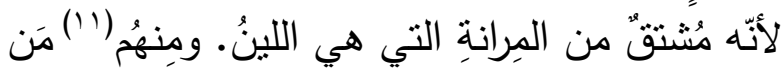

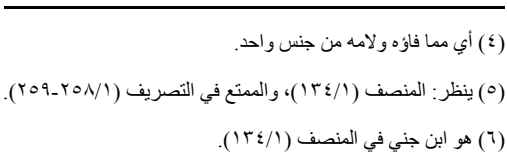

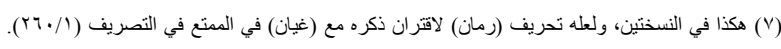

ولأنني لم أجد من ذكر (زنان). أو يكون تحريف "زمان" فقد ورد في المبهج لابن جني (ro (r).

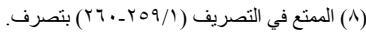

(9) في النسختين "كحران" لكن في النسخة (أ) رسم تحت حرف الحاء (م) استدر اكا من الناسخ فيما أعتقد.

ومران: كما قال المؤلفـ اسم موضع، وهو بالقرب من مكة على طريق البصرة. ينظر : لسان العرب

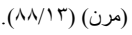

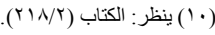

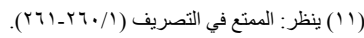

فجميعُ هذه المواضعِ لا تكونُ النونُ فيها إلا

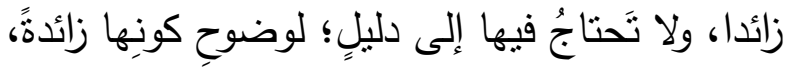

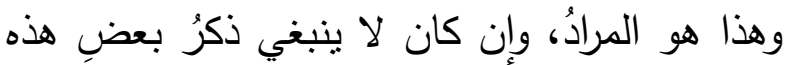

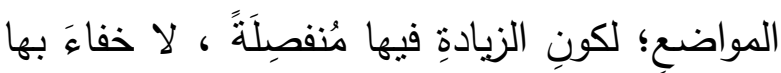

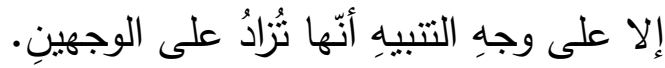

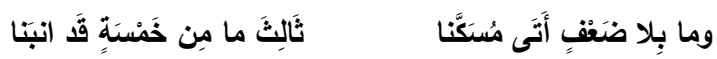

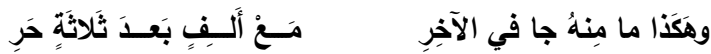

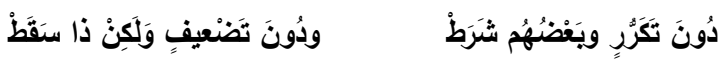

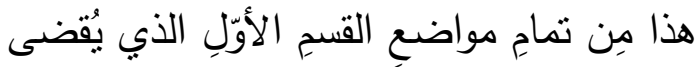

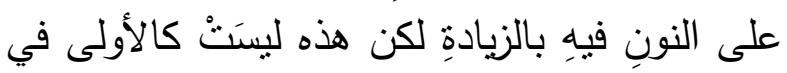

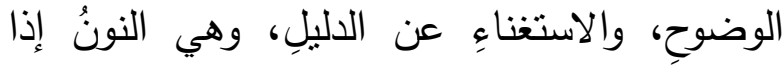

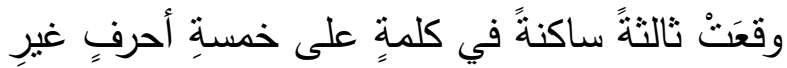

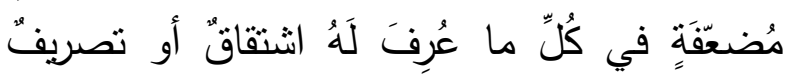

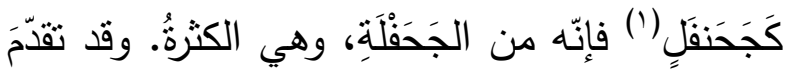

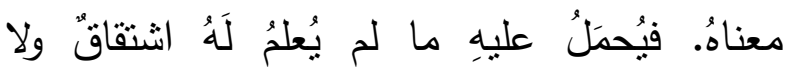

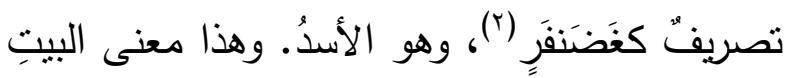

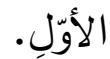

ومتى تخلّفَت شيءٌ من هذهِ القيودِ المذكورة

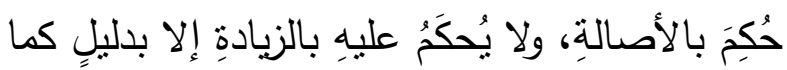

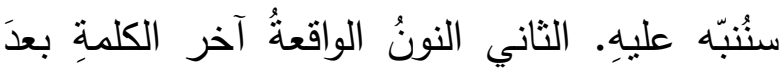

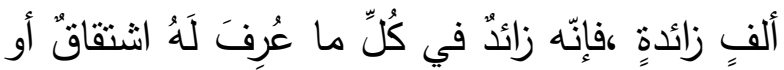

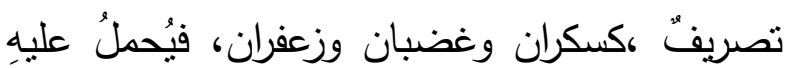

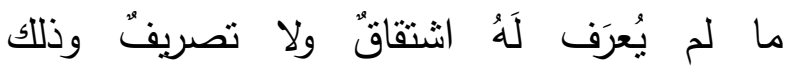

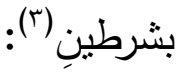




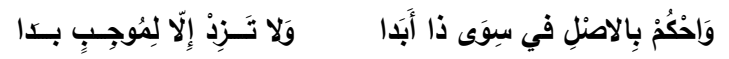

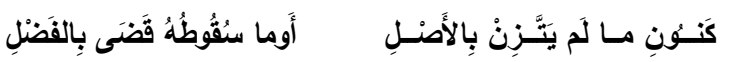

أنشرنا هُنا إلىى القسمِ الثاني الذي يُقضضى فيهـ بالأصالةِ، ولا يُقضى فيهِ بالزيادةِ إلا بدليلِ. فقلَّنا

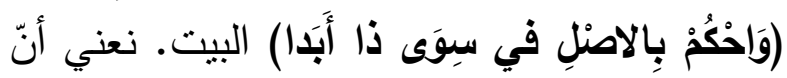

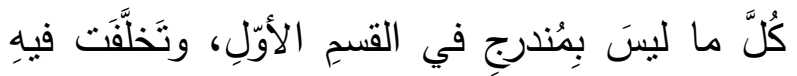

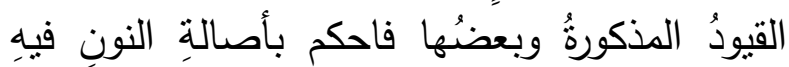

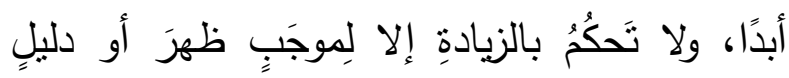

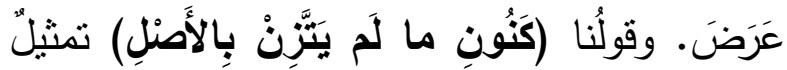

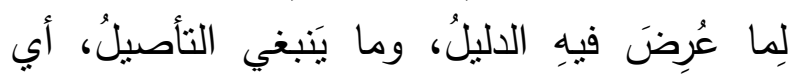

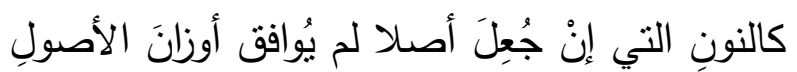

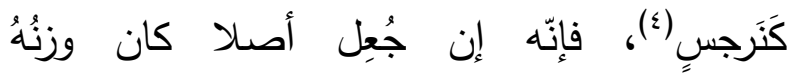

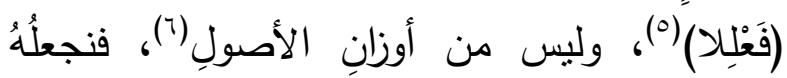

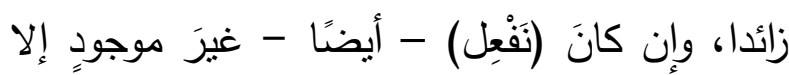

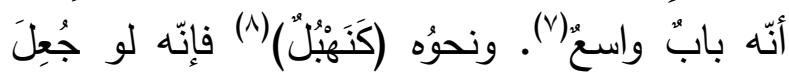

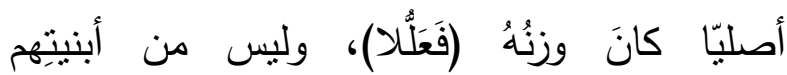

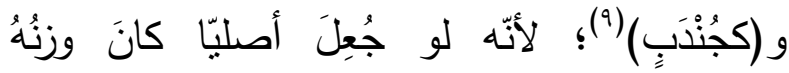

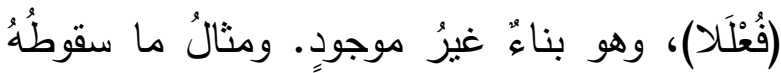

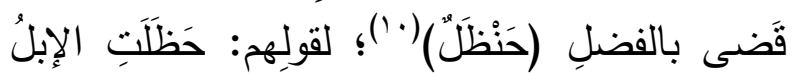

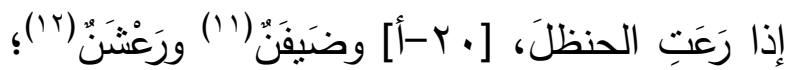

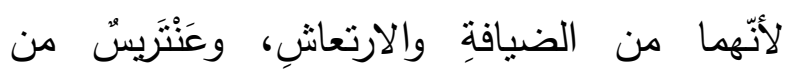

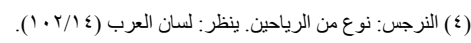
(1) (1) في النسختين (فَعْلِ).

(7) أي ليس في أصول العربية مثل جعفر بكسر اللام الثانية.

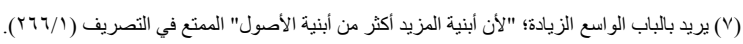

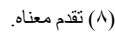

(9) الجندب: الذكر من الجر اد. ينظر : لسان العرب (جدب) (197/ (97) (19).

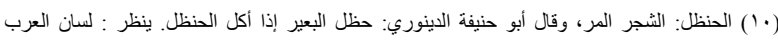
( $(T \pi / T)$ (1) الضيفن: الذي يتبع الضيف. ينظر : لسان العرب (ضيف) (1/1 + (1/). في نونه خلاف منهم من جعها زائدة

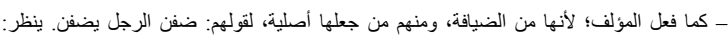

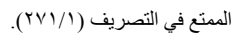

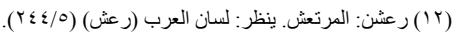

زادَ في هذا الثرطِ كونَهُهُ مضمومَ الأوّلِ اسَّ نباتٍ

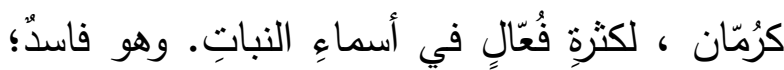

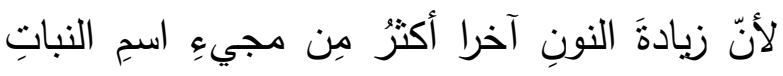

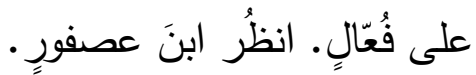

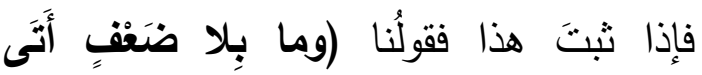

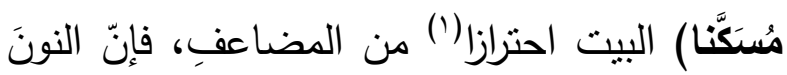

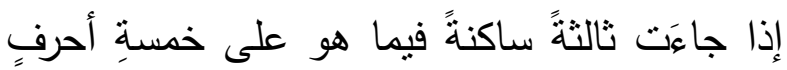

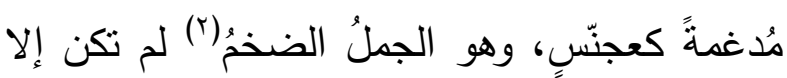

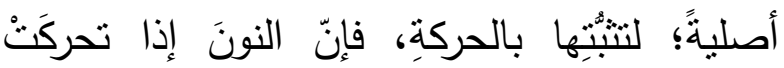

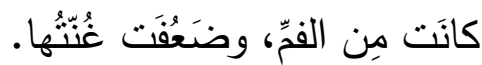

وقولُنا (وهَكَاْ ما مِنهُ جا في الآخِرِ) أبي:

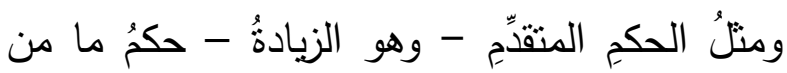

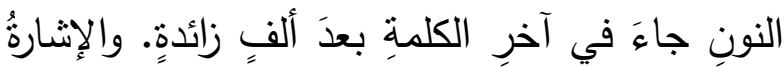

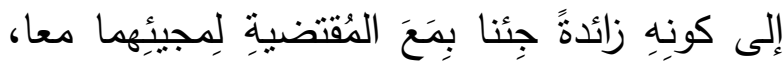

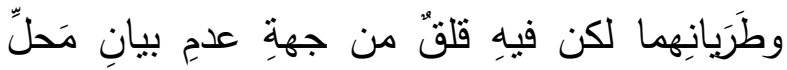

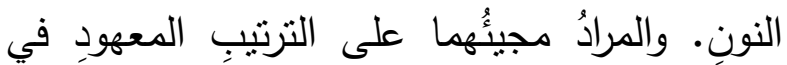

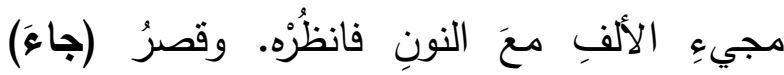

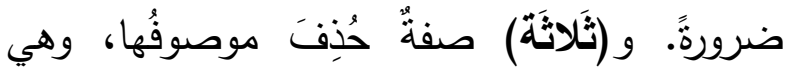

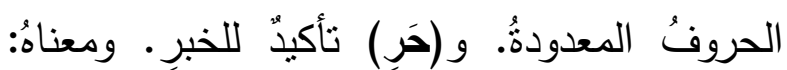

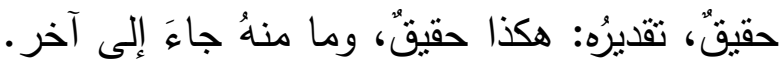

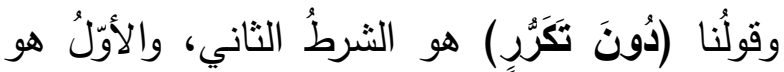

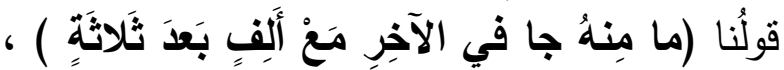

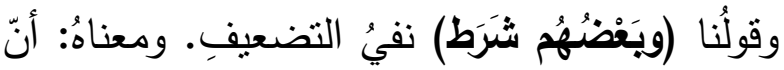

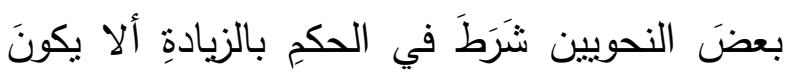

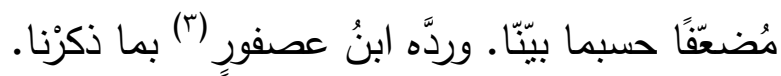


المواضع؛ لانفصالِ زيادتِهِ إلا للتنبيهِ على وجودِ القسمينِ كما ذكرنا في فصلِ النونِ (^).

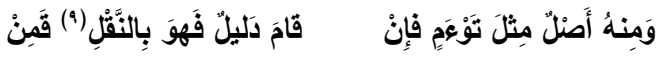

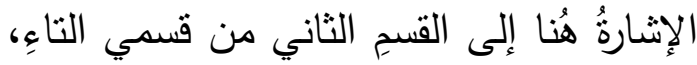

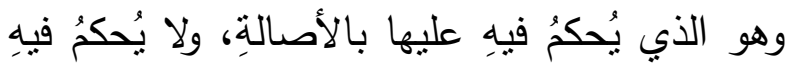

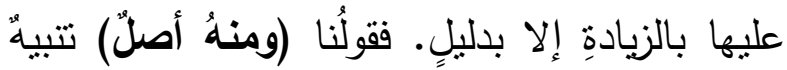

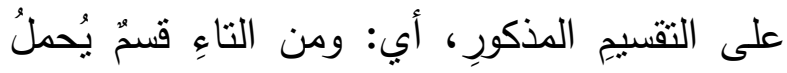

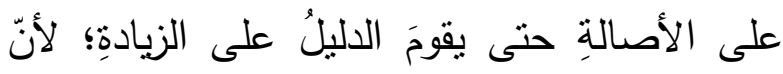

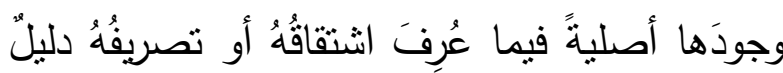

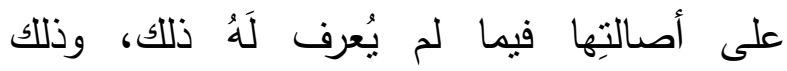

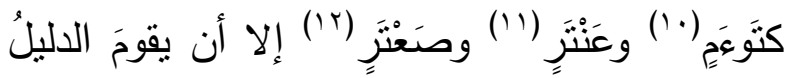

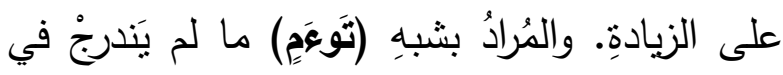

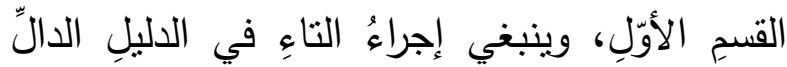

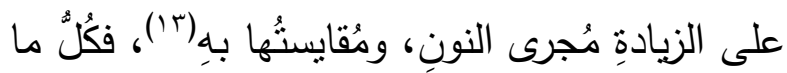

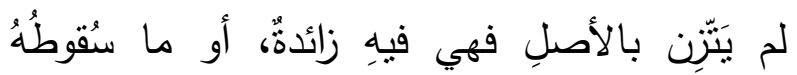

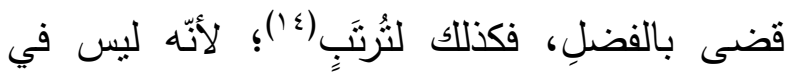

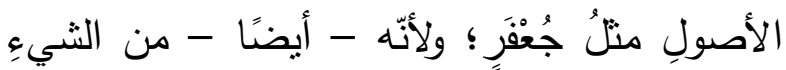

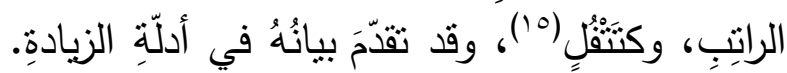

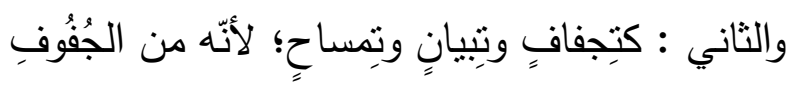
والبيَانِ والمسحِ ولنِ

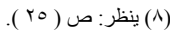

(9) في نسخة (ب) النقل. ( • (1) التو عم: المولود مع غيره في بطن من الاثثين فما زاد. ينظر : لسان العرب (تأم) (r/9). (1') العنتر : الشجاع، وقيل الذباب الأزرق. ينظر : لسان العرب (عنتر) (1V/9 ) (1).

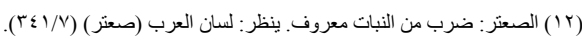

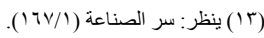

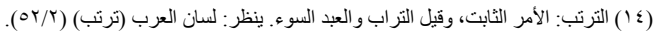
(10) التثقل: الثعلب وقيل جروه. ينظر : لسان العرب (تفل) (r/r (r).

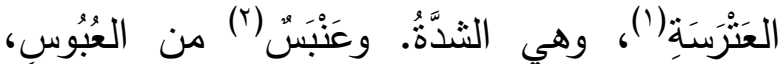

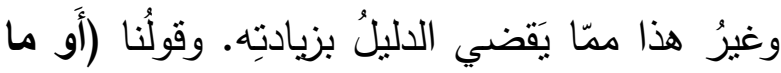

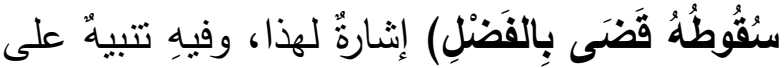
السقوطِ الذي لا يُقضى بالزيادة، كسقوطِ الحرفِ

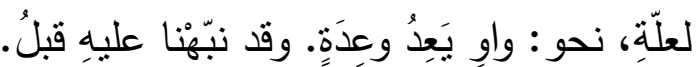

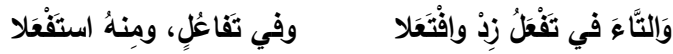

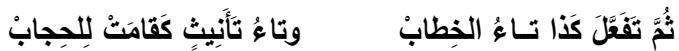

تعرّضْنا للحرفِ الرابع، وبهِ تََّّ الفصلُ الثناني حسبَما قدّمْنا، وهو في حرفِ التاءِ. وهو - أيضًا -

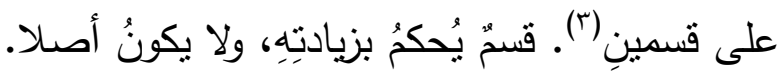

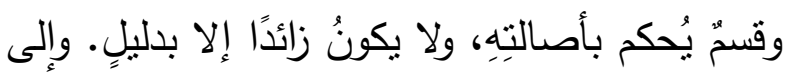

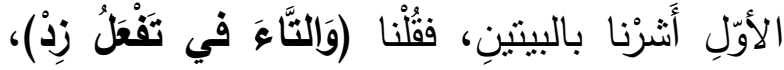

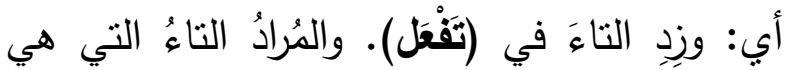

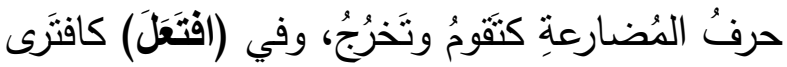

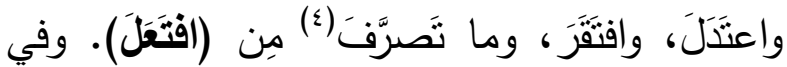

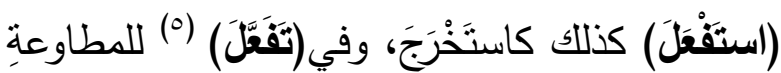

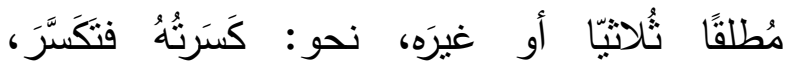

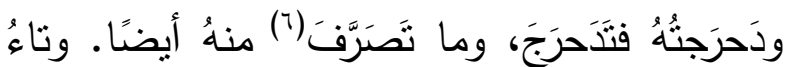

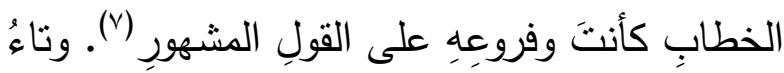

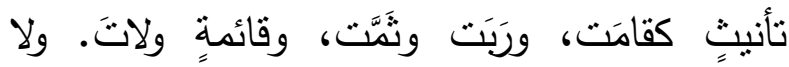

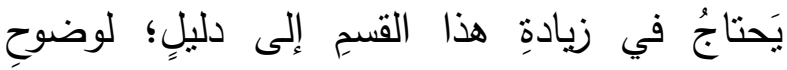
زيادتِهِ، وإن كانَ لا ينبغي ذكرُ بعضِ هذِ

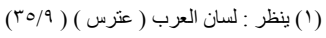

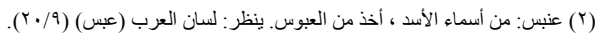

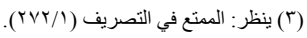

( ) أي نحو: مفترى ومعتدل ومفنتر.

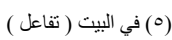
(?) (7) أب نحو: منكسر ومتدحرج. (V) البصريون يرون أن التاء في (أنت) وفروعه زائدة وبعض الكوفيين برون أنها أصلية. ينظر: التصريح

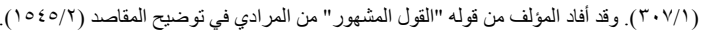


أنّ الألفَ لا يكونُ أصلا بنفسِهِ بل يكونُ إمّا زائدًا و

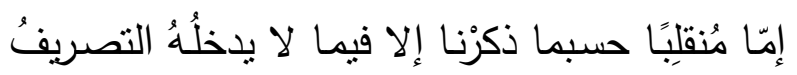

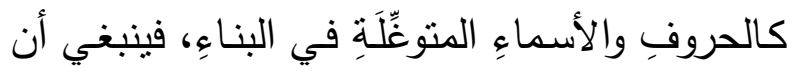

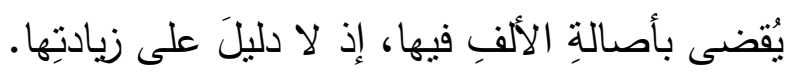

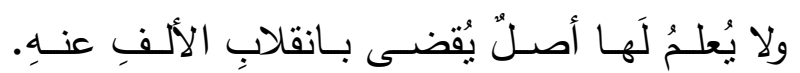

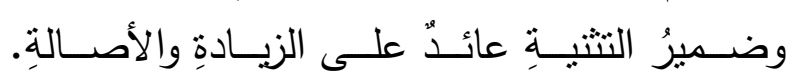

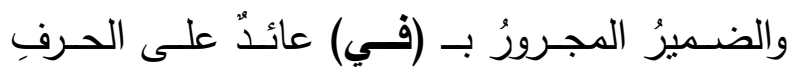

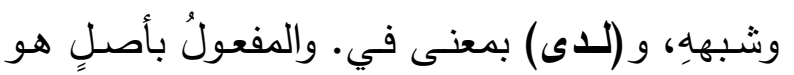

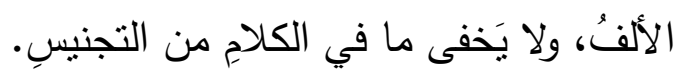

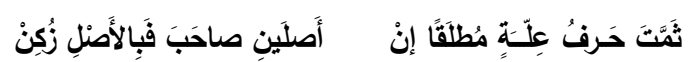

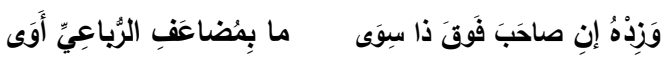

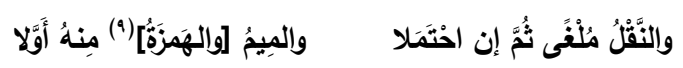

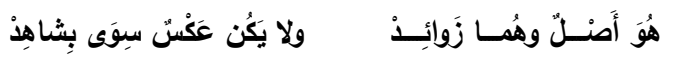

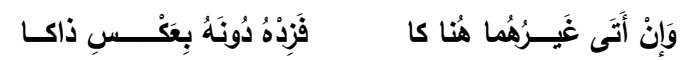

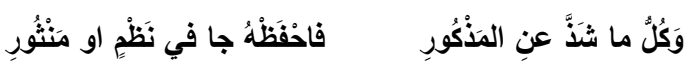
جمعنـا الكلامَ على حروفِ العلّة الألف والواوِ

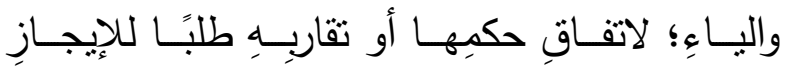

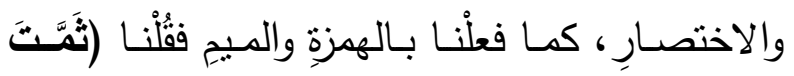

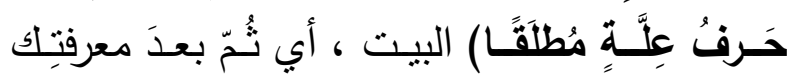
بالمقدمّة المذكورِ في الألفِ.

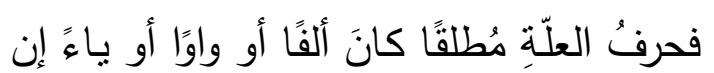

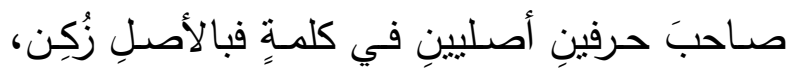

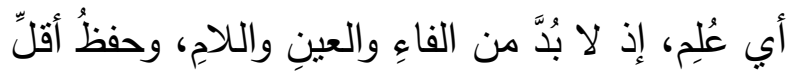

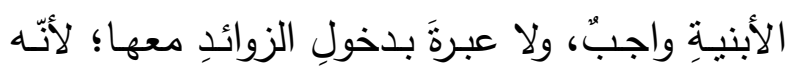
مُلغىى، وقد نبّهنْا عليهِ بعدُ.
واعلَمْ أنّ المواضعَ التي قامَ الدليلُ على زيادةٍ

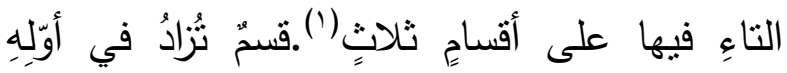

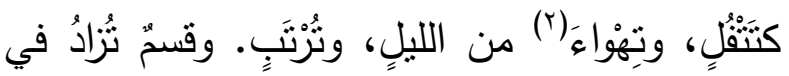

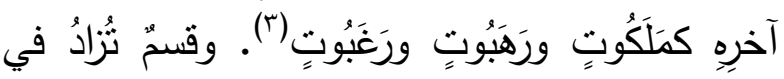

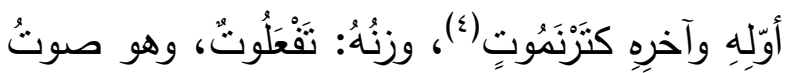

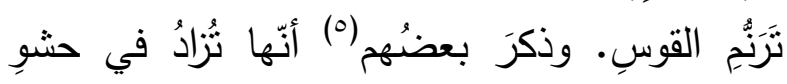

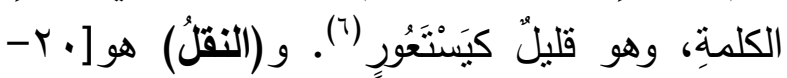

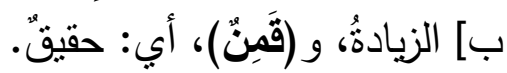

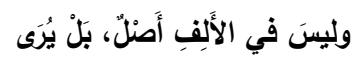

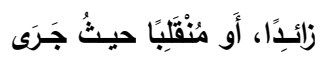

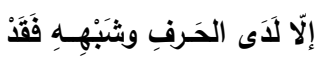

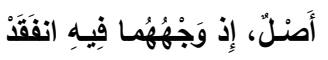

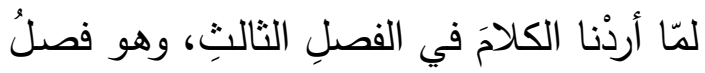

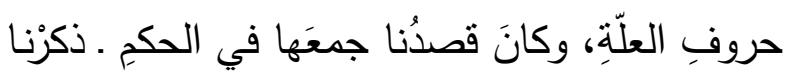

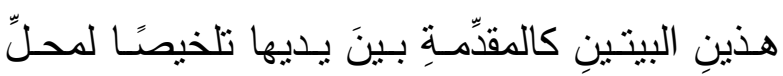

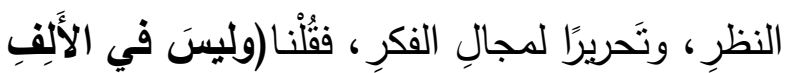

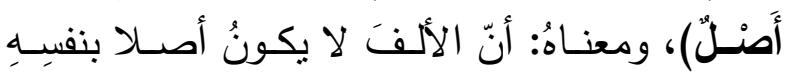

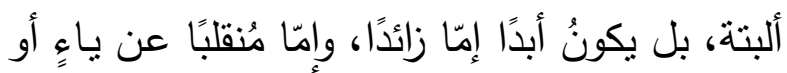

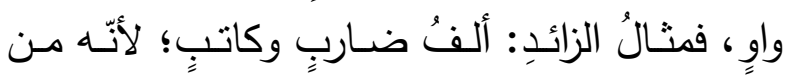

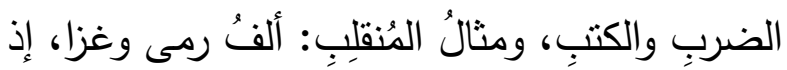

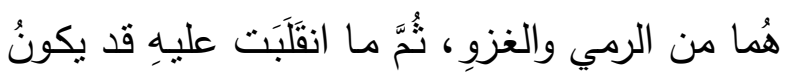

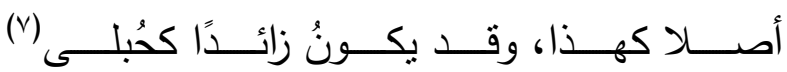

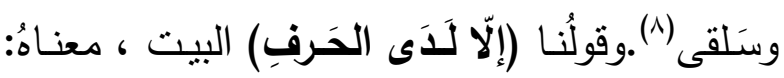

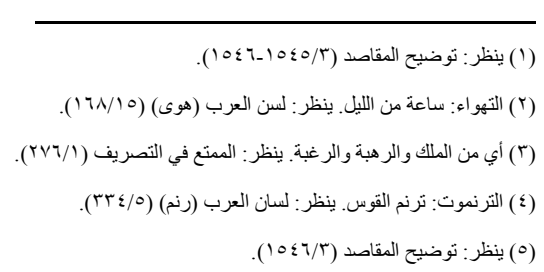

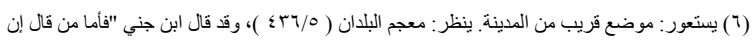

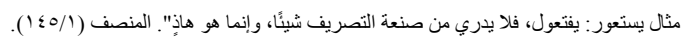

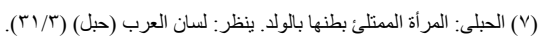

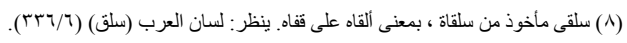




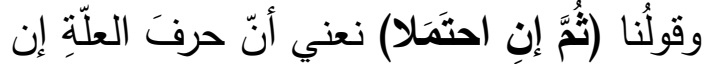

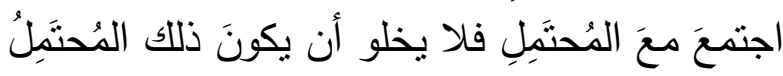

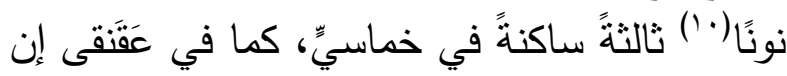

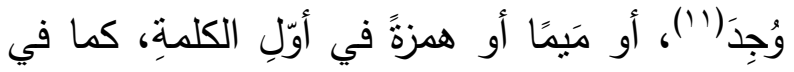

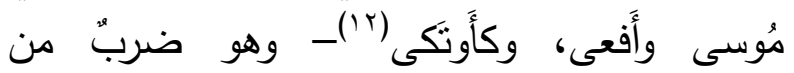

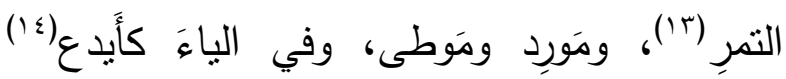

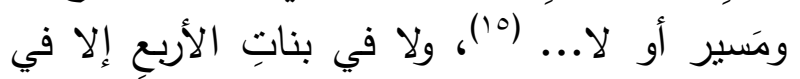

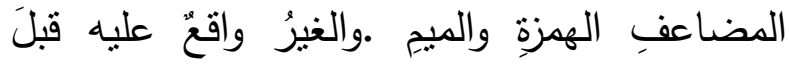

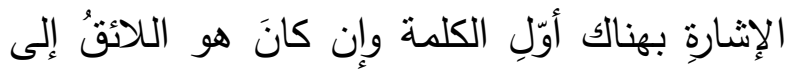

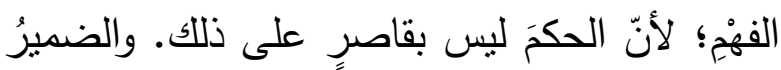

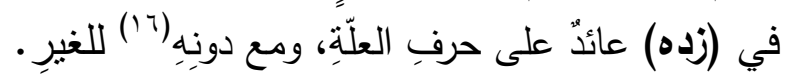
ولمّا وقعَ اللبسُ في قولِنا (فَزَدْدهُ دُونَهُ) رفعْناه

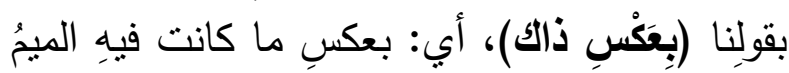

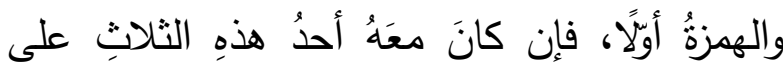

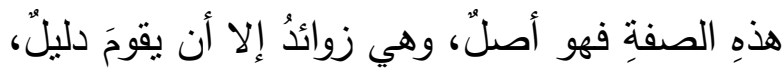

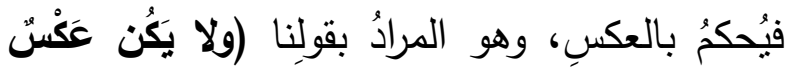

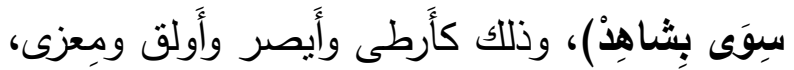

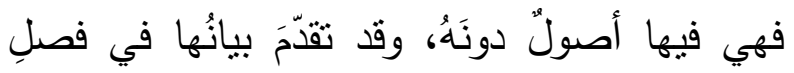

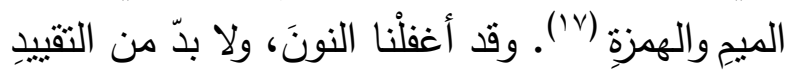

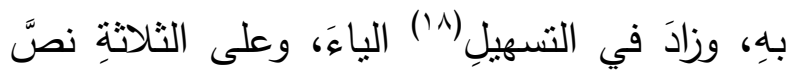

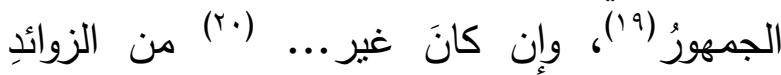

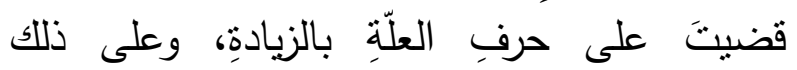

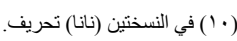

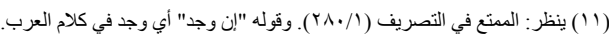

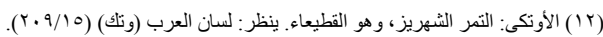

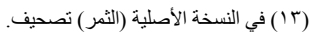

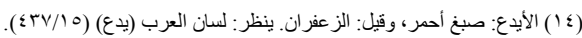
(10) - هنا - أيضًا - سقط، لم ينبه عليه الناسخ. وتقدير الكلام: فإن كان المحتمل من هذه الثثلاثة حكم عليه

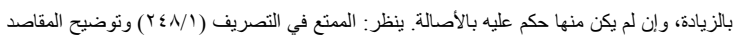

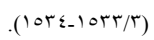

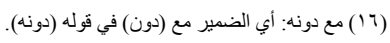

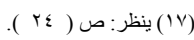
(rवV) (1/)

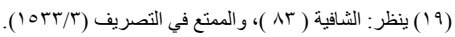

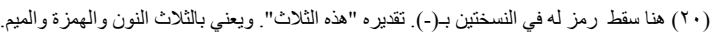

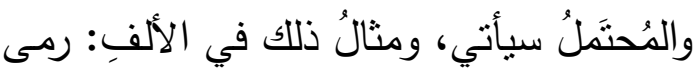

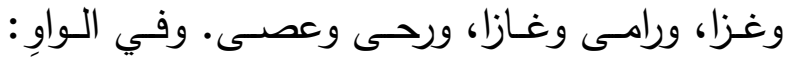

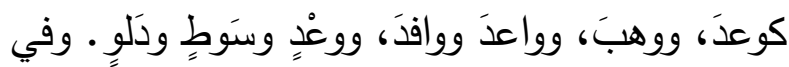

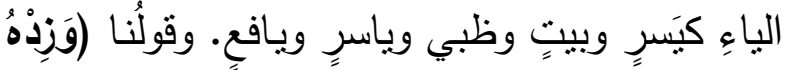

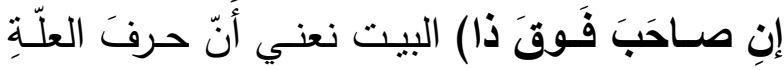

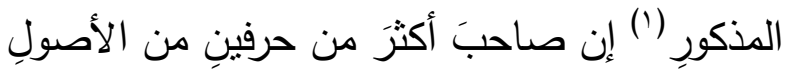

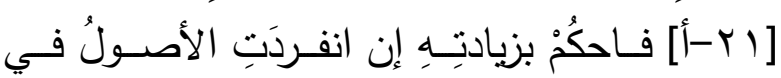

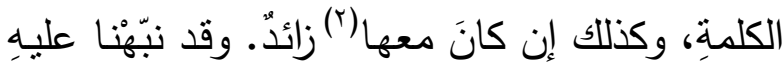

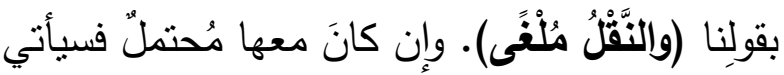

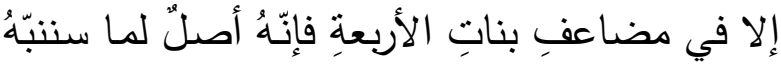

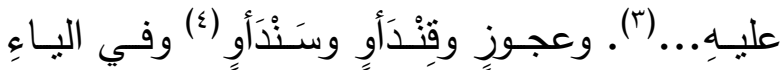

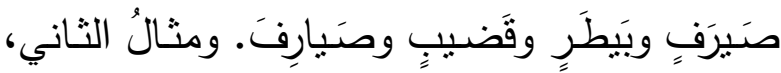

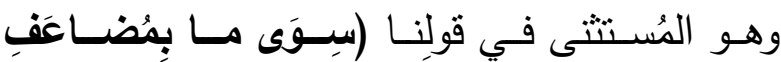

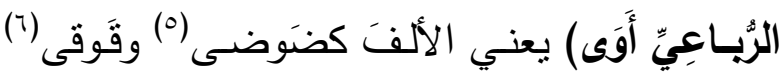

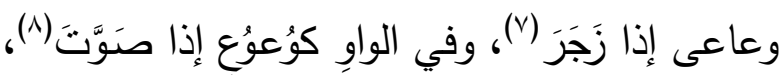

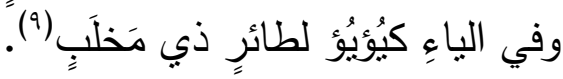

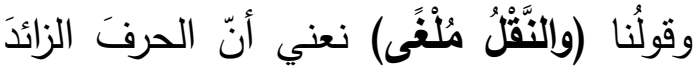

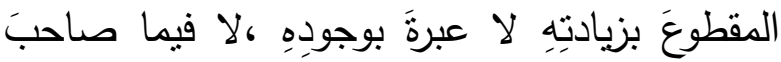

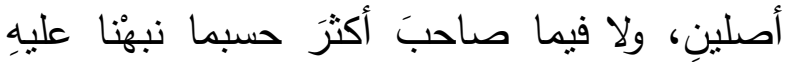

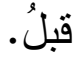

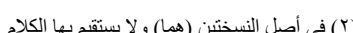

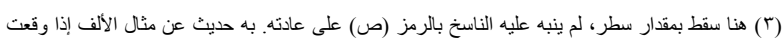

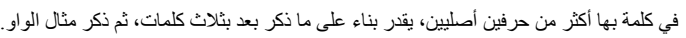

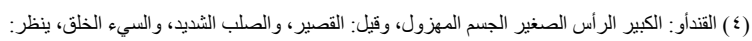

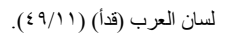

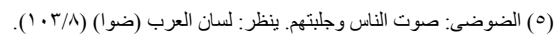

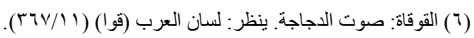

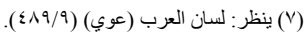

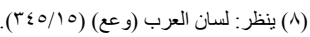

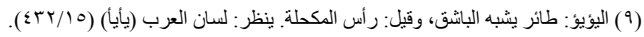


و (المَزيدُ) صفةٌُ حُذِفَ موصوفُهُ، وهو المُبَيَنُ بقولنِا

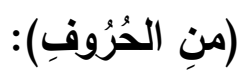

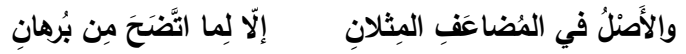

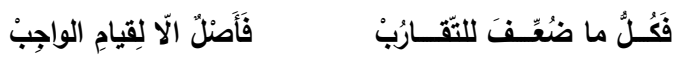

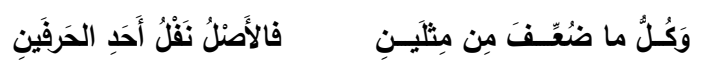

تقدََّ أنّ الغرضَ في هذا القولِ ذكرُ أحكامِ

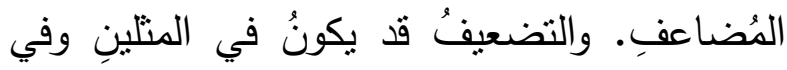

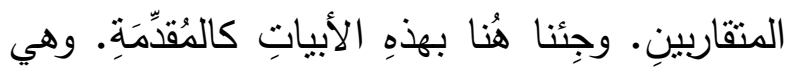

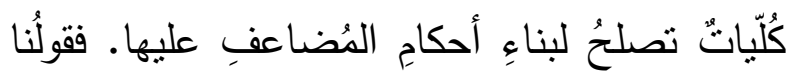
(والأَصْلُ في المُضاعَفِ المِثِلانِ) نعني أنّ الأصلَ

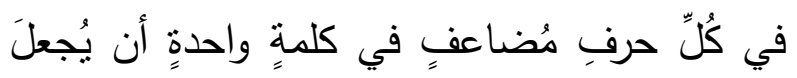
من قبيلِ المِتلينِ، ولا يكونُ من المتقاربينِ إلا بدليلٍِ

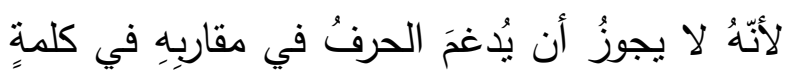

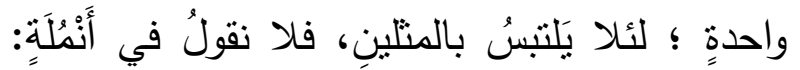

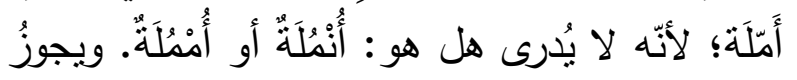

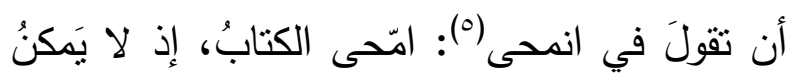

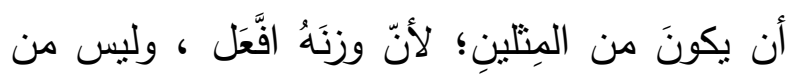

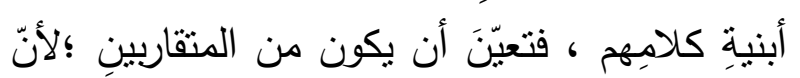

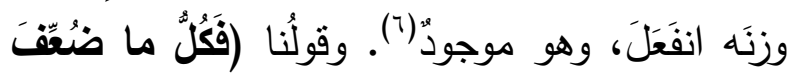

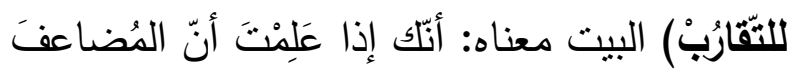

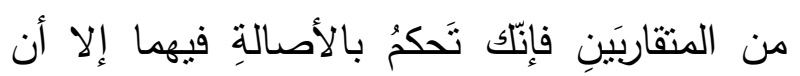

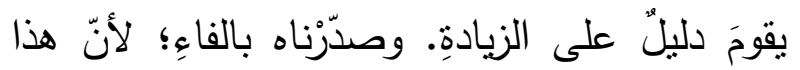

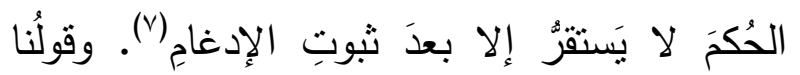

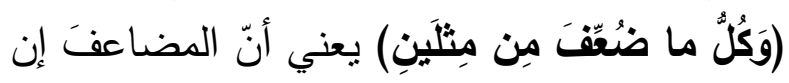
كانَ من جنسِ المِتلينِ فالأصلُ كونُ أحدِهما زائدا،

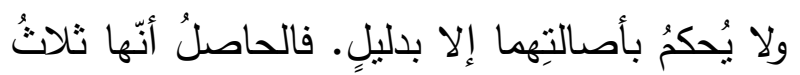

المُحنَمَلِ بالأصالةِ إلا أن يقومَ دليلّ على العكس،

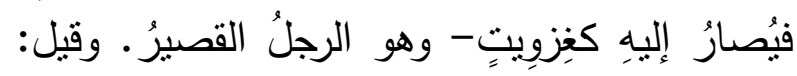

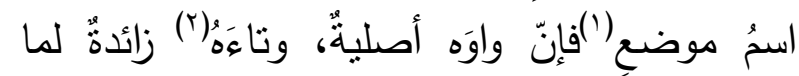

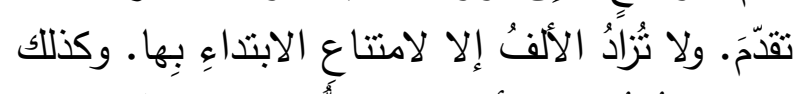

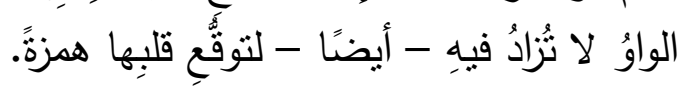

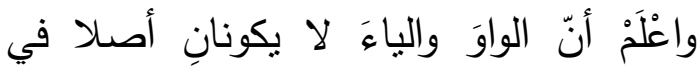

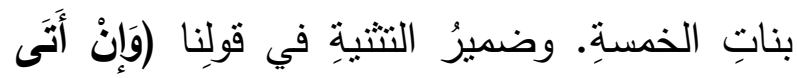

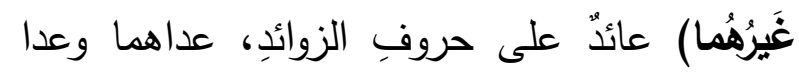

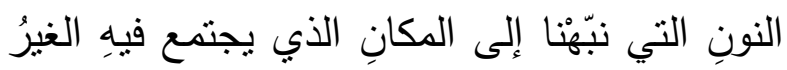

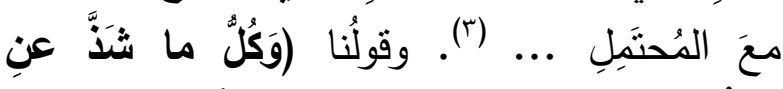

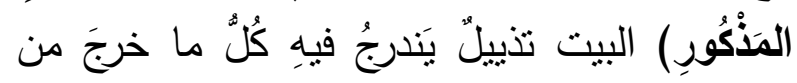

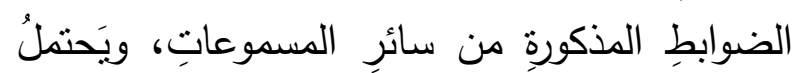
أن يرجعَ إلى فصلِ حرف العلَّةِّ. والأوّلْ أرجحُ.

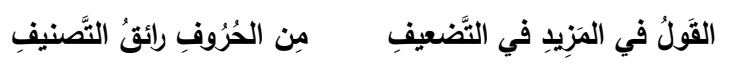

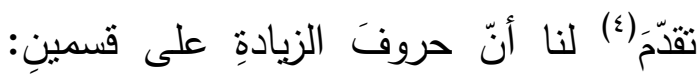

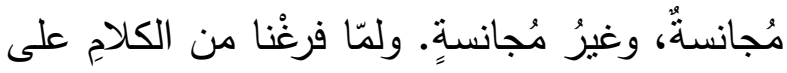

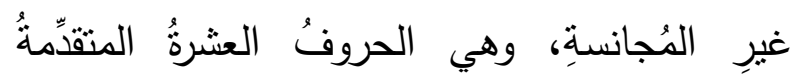

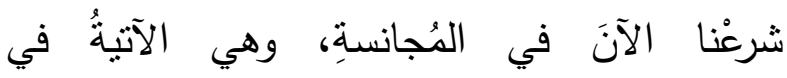

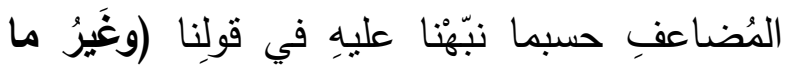

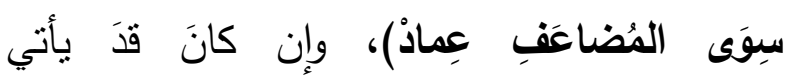
المضاعفِ من الحروفِ العشرة، كما سنُنبِّه عليهِ. ومعنى [اY-ب] البيت: هذا القولُ في ذكرِ المزيد

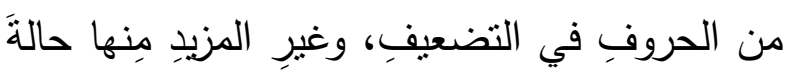

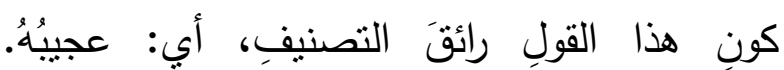




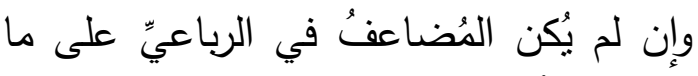

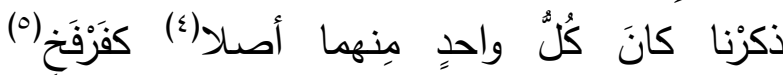

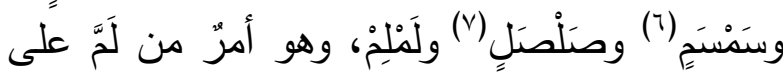

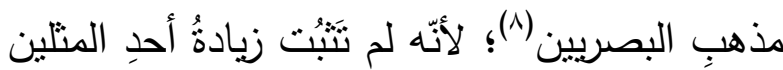

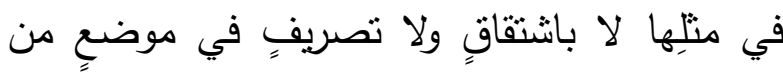
المواضعِ، فيُحملُ هذا عليهِ.

قالَ بعضُهْ (9): إذا تكرّرَ حرفانِ لا أصلَ للكلمةِ

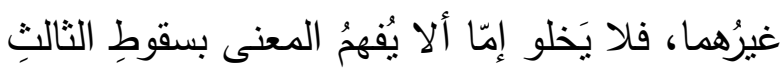

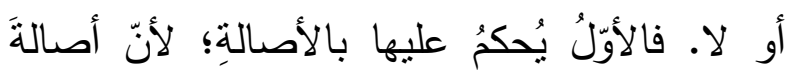

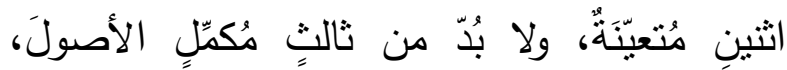

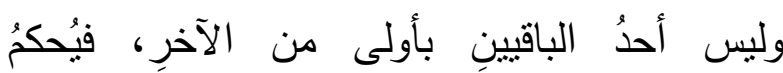
بأصالتِهما. والثاني - وهو أن يُفهَج المعنى بسقوطِ

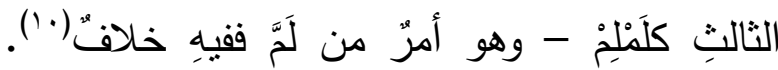

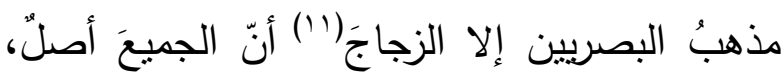

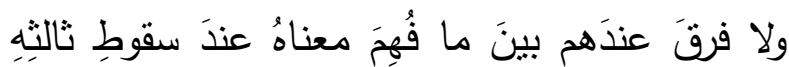

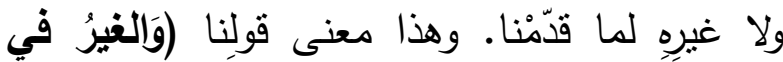

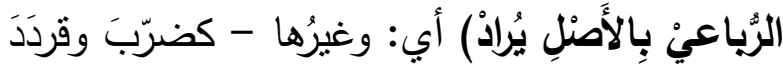

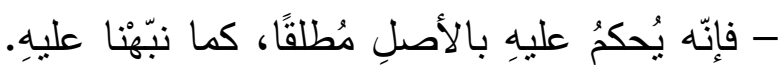

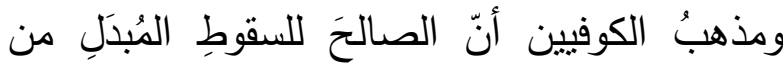

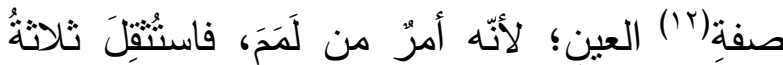

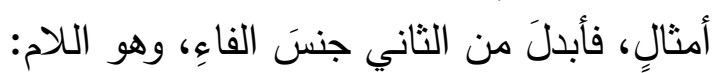

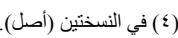

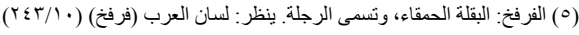

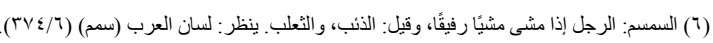

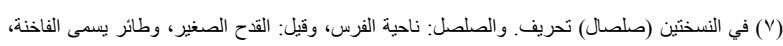

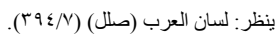

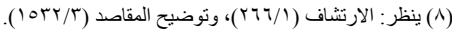

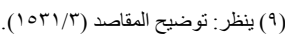

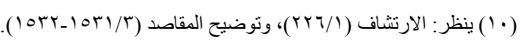

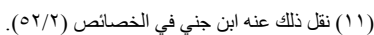

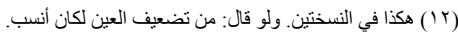

كُُلِّباتِ، هي كالأساسِ للحكِم على الجزيئاتِ في هذا

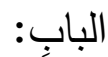

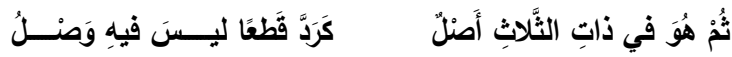

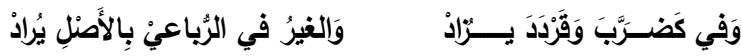

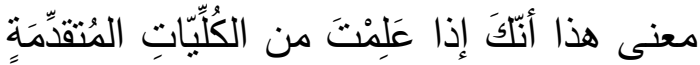

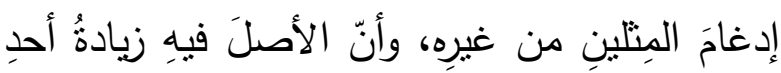

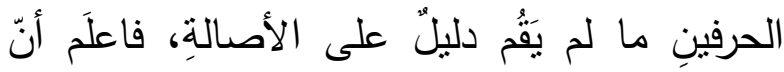

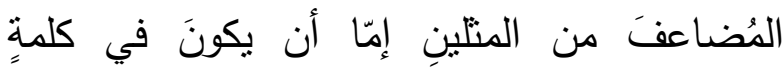

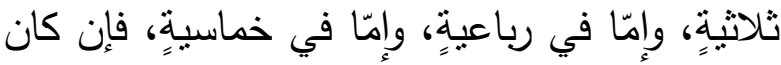

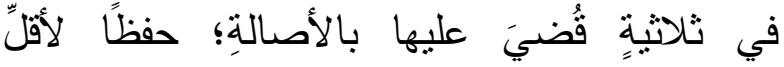

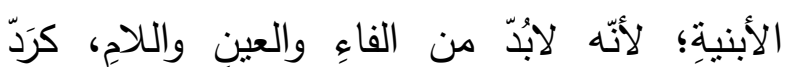
وفَرّ ('). وهذا معنى البيتِ الأوّلِّ.

و (ثُُّم) للترتيبٍ الذي نبّهُنا عليهِ، و (هو) ضميرٌ

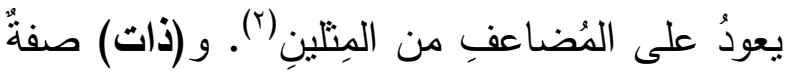

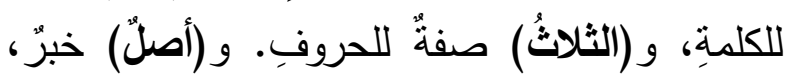

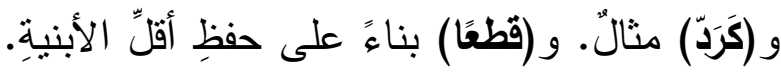

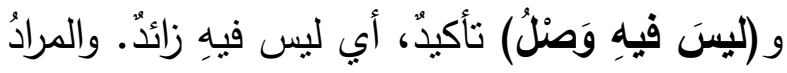

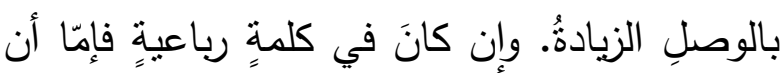

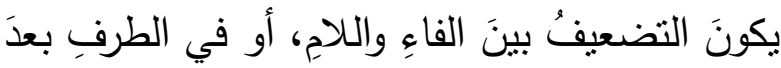

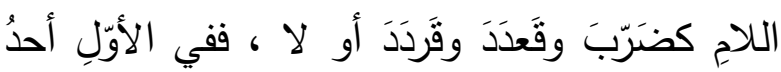

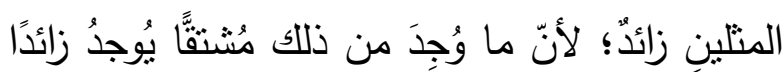

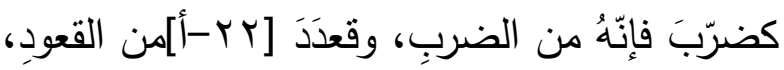

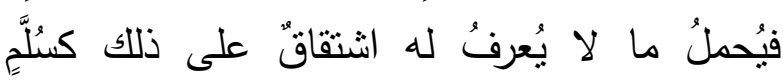

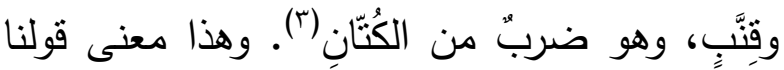

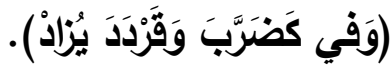


الذي هو موصوفُ الخماسيِّ. أي: و في اللُّناعفِ

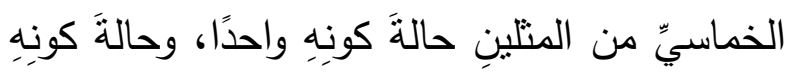

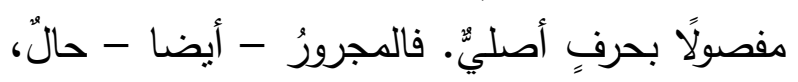

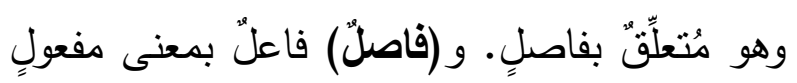

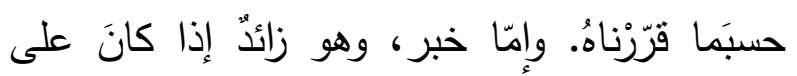
غيرِ هذهِ القيودِ والأحوالِ. والفاصلُ هو الزائدُ.

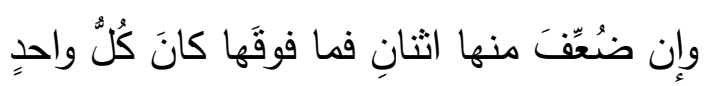

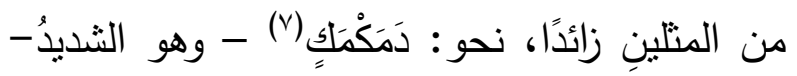

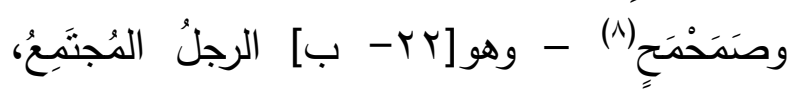
سِنُّهُ ما بينَ الثناثينَ إلى الأربعينَ - أحدُ الميمينِ

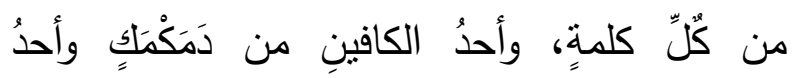

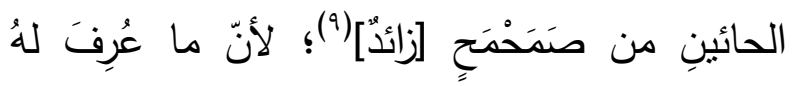

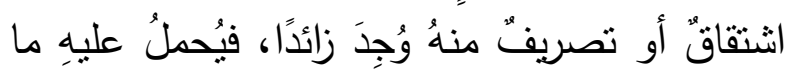
لا يُعرفتُ ذلك فيهـ.

قال بعضُهُم: متى تكرّر حرفانِ، وللكلمةِ أصلٌ

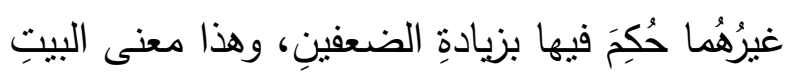

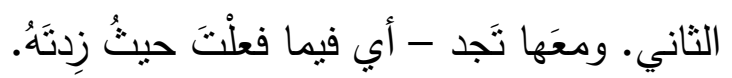

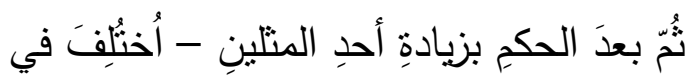

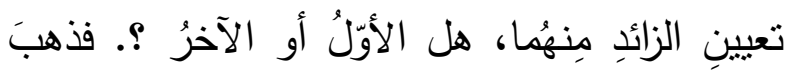

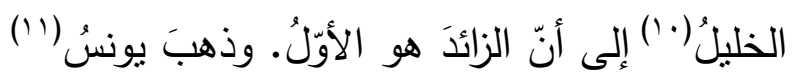

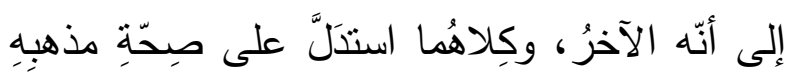

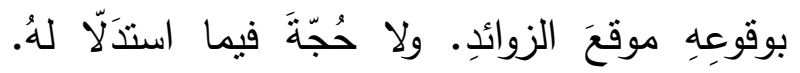
وليسَ فيهِ أكثرُ من التأنيسِ بالنظائرِ. انظرِ ابنَ

(V) الدمكك: من الرجل والإبل القوي الشديد. ينظر : لسان العرب (دمك) (؟/ . ؛ ). (^) الصمحمح: الرجل المجتمع الألواح، وهو في السن كما قال المؤلف ما بين الثلاثين و الأربعين. وقيل:

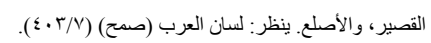

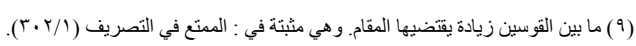

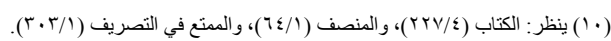

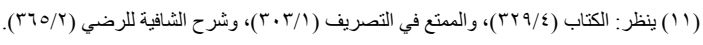

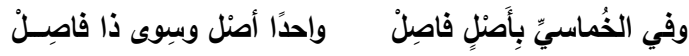

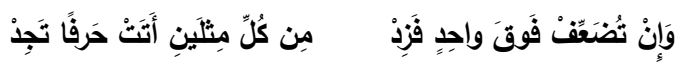

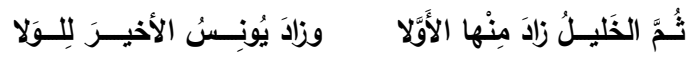
تقدّمَ لنا أنّ التضعيفَ إمّا في كلمةٍ ثلاثيةٍة أو

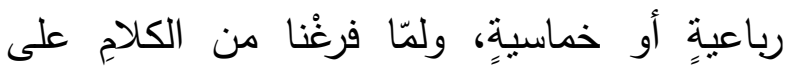

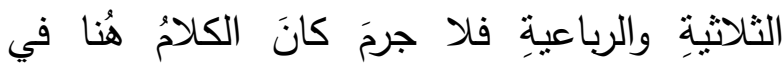

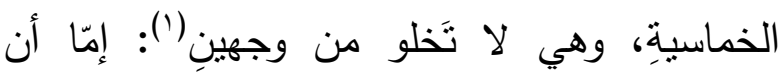

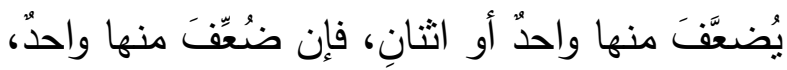

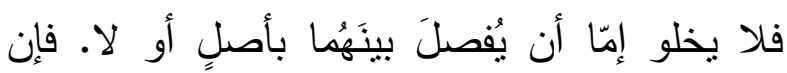

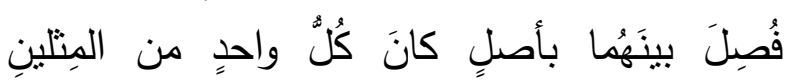

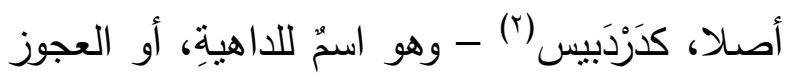

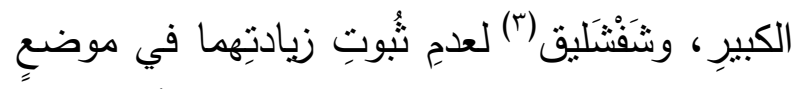

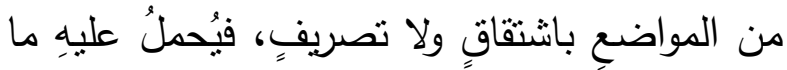

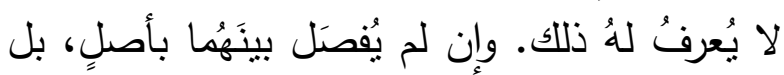

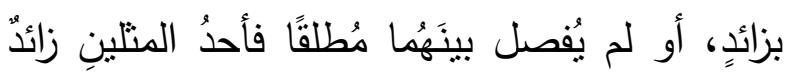

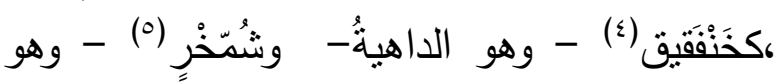
الجسيُمُ من الفُحولِ - أحدُ الميمينِ وأحدُ القافينِ

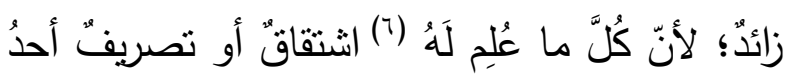

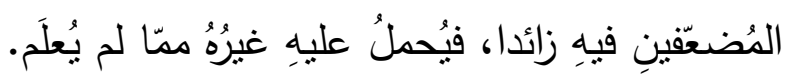

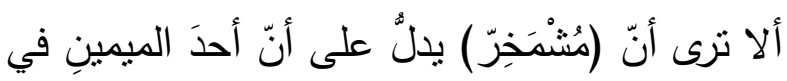

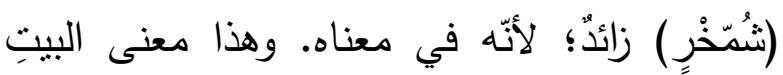

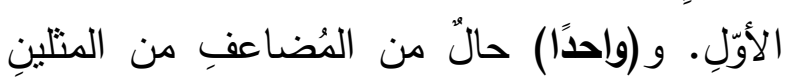

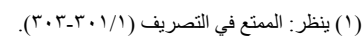
(r) الدردبيس: الداهية و الثيخ الكبير كما قال المؤلف، وقيل: الفيشلة، وخرزة سوداء تتحبب بها المر أة لزوجها.

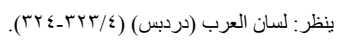

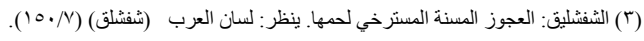

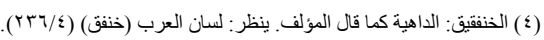
(0) الشخر - بضم الثين وفتحها: الجسيم من الرجال، وقيل: من الفحول. ينظر : لسان العرب (شمخر ) $(1 \wedge 9 / \mathrm{V})$ (†) في النسختين ( ما لله هذه ) ثم هذه العلامة (..). والمثبت من المتع في التصريف ( (T/Y). 
- توضيح المقاصد و المسالك بشرح ألفية ابن

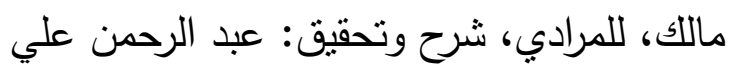
سليمان- دار الفكر العربي-الطبعة الأولى الفي هـ $\leqslant$ ( )

- الخصائص، لابن جني، تحقيق: محمد علي النجار ، دار الثؤون الثقافية العامة، بغداد.

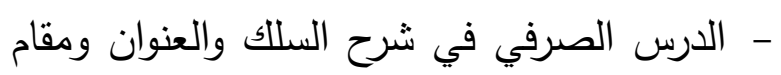

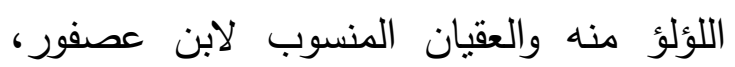

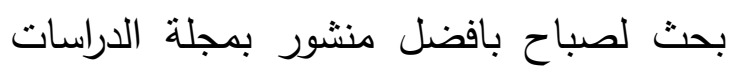
اللغوية والأدبية في الجامعة الإنسلامية بماليزيا،

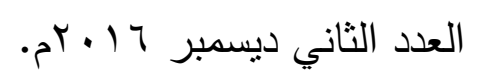

- سر صناعة الإعراب، لابن جني ، تحقيق:

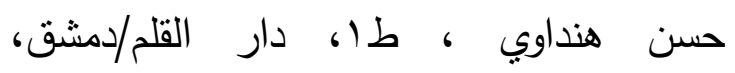
. 910

- الثنافية في علمي التصريف والخط ، لابن

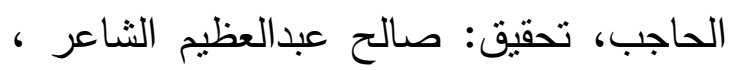

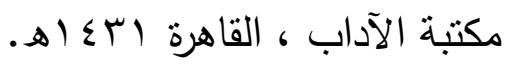
- شرح التصريف، للثمانيني ،تحقيق: إيراهيخ

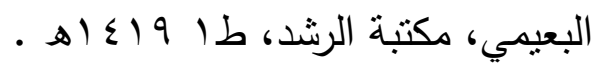
- شرح التعريف بضروري التصريف ، لابن إياز، الهرئ

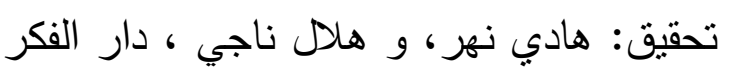

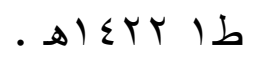

- شرح جمل الزجاجي، لابن عصفور، تحقيق: صاحب جعفر أبو جناح، توزيع مكتبة لانية الفيصلية بمكة المكرمة.

- شرح جمل الزجاجي لابن خروف، تحقيق: سلوى عرب، منشورات مركز البحث العلمي لإني

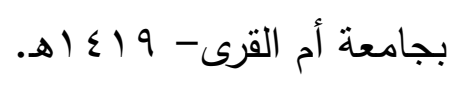

عصفورٍ ('). قالَ سيبويِِ (r): كِلا القولينِ صحيُّ.

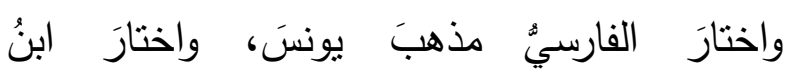

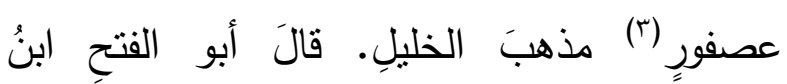

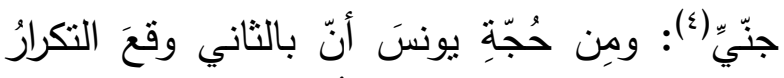

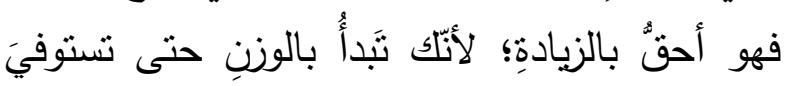

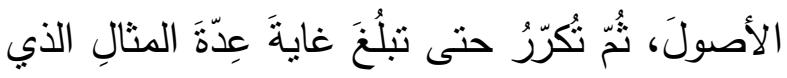

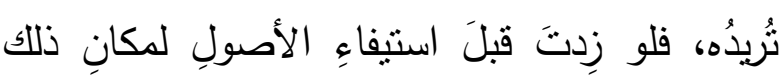

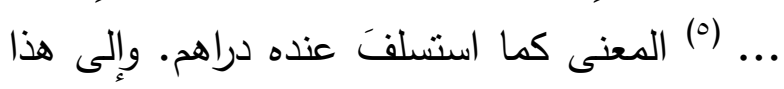
التعليلِ الإثشارٌُ بقولنِا (لَّوَلَا).

\section{قائمة المصادر المراجع}

- ارتنثاف الضرب من كلام العرب ،أبو حيان العزان الأندلسي، تحقيق وشرح ودراسة رجب عثلان الثمان محمد - مكتبة الخانجي بالقاهرة - الطبعة ونان

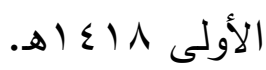
- الأعلام للزركلي، دار العلم للملايين، بيروت ،

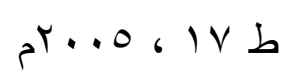

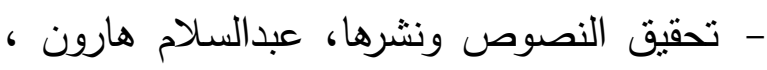

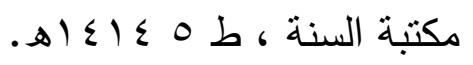

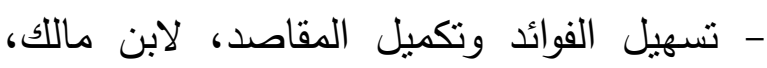
تحقيق: محمد كامل بركات، المكتبة العربية، - $\Delta$ ) $\Lambda V$

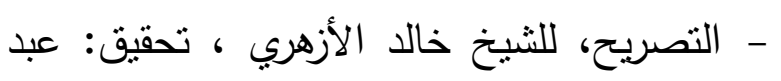

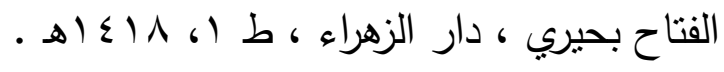




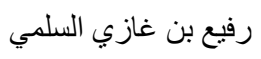

ir.

- لسان العرب، ابن منظور، تحقيق: عامر أحمد وعبد المنعم خليل، دار الكتب العلمية، بيروت، إن،

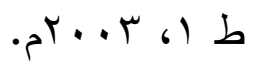

- المفصل في علم العربية، للزمخشري - دار الجيل بيروت طب ، بدون تاريخ.

- المقتضب ، للمبرد ،تحقيق: محمد عبد الخالق

عضيمه - عالم الكتب بيروت-

- الممتع في التصريف لابن عصفور، تحقيق: فخر الدين قباوه ، الدار العربية للكتاب، طه لادئ

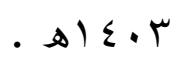

- المنصف، لابن جني، تحقيق: إبراهيم مصطفى

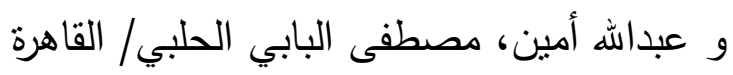

$$
\text { ط ط }
$$

- شرح شافية ابن الحاجب ، للرضي ، عناية: محمد نور الحسن، و محمد الزفزاف، دار

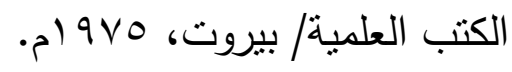

- شرح على السلك والعنوان ومقام اللؤلؤ والعقيان المنسوب لابن عصفور، بحث لزمزم تقي،

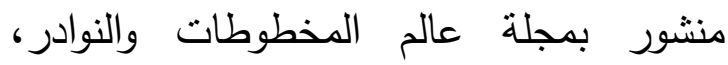

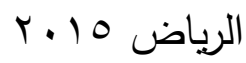

- شرح كتاب سيبويه، للسيرافي ، الأجزاء (0) ، (T) نسخة مصورة عن النسخة الأصلية المحفوظة بدار الكتب المصرية رقم (rv)

نحو).

- شرح الملوكي في التصريف، لابن يعيش، المكتبة العربية / حلب ،طس 9 (، ام.

- الكتاب، لسيبويه، تحقيق: عبد السلام هارون،

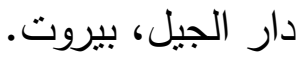




\title{
The Silk: The Poetic system of The Morphology Prose of lbn Asfur (by an Unknown Scholar from the Eighth Century AH) Studied and edited by
}

\author{
Rafi' Ghazi al-Sulami
}

\begin{abstract}
This book is written in poetic structure. It adopts the poetry as a style to write down the subjects of morphology. The author of the book is an unknown scholar (he belongs to the eighth century $\mathrm{AH})$.

The most important results of this research include the following:

1) The silk book has a scientific value among grammarians.

2) The author of this manuscript has a specific opinions in the topics of morphology.

3) The same author was acquainted with the knowledge of Arabic.

4) The science of grammar stayed active in Arabic Islamic culture through out ages.

5) Writing grammar and morphology in a poetic style was valid in Islamic civilization for educational purposes.
\end{abstract}

Keywords: Ibn Asfur- grammar and morphology - Arabic manuscripts 